\title{
Predicting Bankruptcy and Financial Fraud of Both Listed and Unlisted Commercial Banks in Ghana Using 3 Z-Score Models
}

\author{
Thomas hezkeal Khela Nan ${ }^{1,} \quad$ Bimpong Patrick $^{1^{*}} \quad$ Richmond Kwesi Ansah ${ }^{2}$ \\ Danso Edward ${ }^{3} \quad$ Tabiri Anthony ${ }^{4} \quad$ Arhin Ishmael $^{5}$ \\ 1.School of Accounting; Zhongnan University of Economics and Law-China; (182\# Nanhu Avenue, Wuhan \\ 430073, P.R. China) \\ 2.Hong Kong Baptist University; Africa Centre for Entrepreneurship and Youth Empowerment \\ 3.Department of Accounting; University of Education, Winneba-Ghana; (P.O. Box 25, CE-052-8664.) \\ 4.School of Business and Law ; University for Development Studies-Ghana; (Box TL 1350, Tamale, Ghana. NT- \\ 0272-1946) \\ 5.Dokuz Eylul University-Turkey
}

This research did not receive any source of external finance.

\section{Abstract}

The purpose of this study was to assess the possibilities of bankruptcy and financial statement fraud in Ghana's banking sector. An investigation of the financial statements of the banks for the period 2015 to 2018 was made with the use of Altman's (2000), Taffler's (1983), and Beneish (1999) models. The Altman (2000) and Taffler (1983) models are predictors of insolvency or bankruptcy. To unveil the possibilities of financial statement fraud, this study used the Beneish [1999], model. The examination of the bank's annual financial reports with the Beneish model revealed the banks were engaged in earnings manipulation. The Altman [2000] and Taffler [1983] models, on the other hand, brought to light the financial soundness of the banks with an average of $14(74 \%)$ and $18(95 \%)$ of the 19 selected banks correctly classified into the safe zone with an impressive Z-Score performance according to Altman and Taffler's models respectively. The study, therefore recommends that, if the Beneish model is applied well together with the failure prediction models by researchers, it can provide a reliable finding for policymaking. Also, auditors, investors, management, and stockholders when making good use of the Beneish model, it can provide potential 'red flags' for further investigation to be carried out for better audit assignment

Keywords: Altman [2000] Z-score model, Beneish [1999] M-score model, bankruptcy, commercial banks, fraud, financial statement, Ghana, Taffler [1983] Z-score model.

DOI: $10.7176 / \mathrm{EJBM} / 12-12-05$

Publication date: April $30^{\text {th }} 2020$

\section{Introduction}

For decades, financial bankruptcy prediction has been a central topic in both practical and academic corporate finance. From a practical perspective, creditors, stockholders, senior management, and auditors are all interested in failure prediction because it greatly influences their decision making. Also, financial bankruptcy leads to serious social problems, such as economic depression, financial crisis and unemployment particularly if several institutions run into financial bankruptcy at the same time.

There are several names attributed to the financial ill-health of an institution, specific meanings have been given specifically to described ill-health of an institution. Names that have been notably used to describe the financial ill-health of an institution include corporate/business failure, insolvency, and bankruptcy. Adeyemi [2011] defined bankruptcy situations to mean having financial operational and managerial difficulties. Vuran, [2009] defined business failure as the situation when the institution cannot pay lenders, shareholders, and suppliers, etc., or the institution is bankrupt according to the law. Baharin and Sentosa, [2013] defined financially bankrupt firms or banks as institutions that are experiencing financial difficulties to maintain their normal operations.

Usdin and Bloom [2012] have identified nine signs of financial bankruptcy as follows: the company cannot timely pay for creditors; the company suffer a significant event that will not recur; the liabilities of the company are greater than its assets; the company's lender or bank threatens to shut down operations of the company; the company's business model no longer becomes viable; a union threatens some type of action against the company; the company is sued in collection matters; a major supplier threatens to terminate services to the company, and the company cannot perform its contracts on time or cannot perform its contracts at all. Sami [2013] indicated that financial bankruptcy is tied to cash flow problems and incapacity of debt settlement. The institution will meet three difficulties: it loses the right to make decisions; the financial bankruptcy can reduce the demand for the product of the institution and increase production costs, and managers require a considerable amount of time to solve the financial bankruptcy.

Chen and Zhuang [2014] indicated that the financial state of a company often cannot be observed directly, but only some indicators associated with the financial state can be observed. In their study, they established a model that is used to describe the correlation between the signal indicators and the financial state of a firm. Baharin 
and Sentosa [2013] indicated that the institutions that generate a lower rate of return compared to the market rate for similar investments, having average return that is lower than the cost of capital, and/or do not have enough revenue to meet their expenses can be considered as experiencing business failures.

According to Kammani, [2017], the banking system is considered one of the pillars of the financial system of any economy. The banking system ensures the sustainable economic development and welfare of any society by forming adequate capital and allocating funds efficiently for investment projects, and payment for services. Financial institutions in general and banks, in particular, bring together those who require funding and those who possess surplus funding [Kumari, 2017; Choudhry, 2018]. In developing countries like Ghana, the banking sector is even much more important. According to Sarker, Ghosh \& Palit, [2015], greater financial inclusion can have a positive effect on the lives of the poor in the country, Moreover, financial health appraisal of financial institutions in general and banks, in particular, is critical [Mwawughanga \& Ochiri, 2017]. So, financial bankruptcy in the banking sector has much more dangerous results than it has in the business sector.

Recent studies indicate there is bankruptcy throughout the world. During these last years, the annual flow of bankruptcy did not stop increasing and this trend becomes more marked during periods of crisis [Sami, 2013]. Specific reference to some renowned corporate failure can be made of General Motors (GM), Chrysler, American International Group Inc., Delta Airline Limited Xerox, AIG, Freddie, WorldCom, Lehman Brothers, and Enron Corp [Mclntyre \& Ogg, 2008]. In Ghana, previous cases of bankruptcy include Bank for Housing and Construction, Ghana Co-operative Bank, National Savings and Credit Bank, UT Bank, DKM financial and Gateway Broadcasting Services [Appiah, 2011]. A case of corporate failure that is still fresh on the minds of Ghanaians is the collapse of UniBank Ghana Limited, Royal Bank Limited, Beige Bank Limited, Sovereign Bank Limited, and Construction Bank Limited because of liquidity and solvency challenges. Among the reasons cited for the collapse of these Banks were the Corporate governance issues, Asset Quality, liquidity and solvency challenges faced by the banks [Bank of Ghana, 2018].

Many studies support the need for the expectation of financial bankruptcy and the likely occurrence of financial bankruptcy and failure of banks. Glautier and Underdown [2001] point out that an early warning signal of probable bankruptcy and failure will enable both management and investors to take preventive actions. The warning signs and $\mathrm{Z}$ score model have the ability to help management for expecting problems early to avoid financial difficulties [Ray, 2011]. The expectation of failure as early as possible with sound accuracy will enable firms to take action to reduce the costs of bankruptcy, avoid failure to all stakeholders and contribute to achieving the business and financial environment stability [Gharaibeh et al., 2013].

Business news and Bank of Ghana Annual report on the Ghanaian banking sector within the last three years [2016 to 2019] reveal that over 16 banks in Ghana have been creased up or collapse completely as they were fronting financial difficulties. Ghanaian UT bank started in 1997as a financial house named as Unique trust financial services. According to Ghanatrade, [2017] the financial services house purchased a former bank that is called BPI bank in June 2010 and was listed on the Ghanaian Stock Exchange as UT Bank, yet after six years, it has folded up. In 2009, Capital bank was established as savings and loans and got a license to operate as a bank in 2013 and three years after, it has collapsed. In August 2018, the Ghanaian central bank announced the collapse of five banks named as follows: Unibank, Sovereign Bank, Beige Bank, Royal Bank, and Construction Bank. Other banks such as GN bank and other financial institutions have also are indicated signs of failure. The phenomenon happening in the Ghanaian economy cast doubts on the interest of Ghanaians regarding which banks are safe for both depositors and investors to lodge their hard-earned money. Also, workers in the banking sector are worried about their Job security as thousands of workers have to lay off at the collapse of the bank. Taking into account the frequent mergers, acquisitions, collapse and winding up of Ghanaian banks from 2016 to 2019 with its associated capital loss, employment loss, and socially undesirable results, it is important to view bankruptcy assessment as rudimentary in the financial sector. This study, therefore, apply Altman [2000] and Taffler [1983] Z- scores to examine the financial health of both listed and unlisted commercial banks in Ghana. In addition, Beneish [1999] M-score model was equally employed to detect the possibility of earnings manipulations in the publicly published annual financials of the understudy banks. The originality of this study is to extend the application of Altmann [2000], Tattler [1983] and Beneish [1999] Model on both indigenous and multinational Commercial Banks in Ghana which has not been previously carried out in the practice for bank failure assessment. This paper thus makes use of the most important and widely accepted accounting-based predictive models. To the best of my knowledge, a study of this nature has not been conducted in Ghana specifically in the banking sector.

Altman's Z model is one of the best- known models, statistically derived predictive model that is used to predict a firm's bankruptcy [Moyer, 2005]. Altman is a very famous financial economist and professor at New York's Stern School of Business developed Altman's Z score model in [1968]. The Z-Score approved by management accountants, auditors, and database systems beginning in the mid-1980s. Although, Edward Altman originally developed the Z-Score based on a small sample of manufacturing firms. Altman's Z-Score formula is a multivariate formula that is used to measure the financial health of a company and to predict the probability that a 
company will go bankrupt within two years. The Z-Score uses various financial accounting ratios and marketderived price data to expect bankruptcy. In the early 2000s, Altman modified the model to apply to certain situations not originally included in the original sample set. Even though the model is worldwide accepted, however, it has its own limitations. Prominent among these is the possibility that secondary data used to estimate the independent variables might be manipulated and this manipulation will affect the predictive ability of the model. To deal with this limitation, professor Beneish [1999] developed eight indexes for detecting potential earning manipulations in the financials published by corporate institutions. This model has been tested by a large number of scholars and proved effective in detecting earning manipulations. Following Altman [1968] is professor Taffler 1983 developed Z-score. Taffler suggested failure model should capture vital corporate solvency and performance indicators such as profitability, working capital adequacy, financial risk, and liquidity. To establish the authenticity of the result, this paper employed all the above-mentioned Models.

\section{Theoretical Framework and Literature Review.}

The examination of corporate failure prediction can be categorized into three broad areas: First, developing a prediction models and it often provides general index which can be used to measure the possibility of failure, such as the study of Zeytunoglu \& Akarim (2013); Altman (1968); Christidis \& Gregory (2010); Beaver (1966). The Second field looks at the assessment of the validity and predictive accuracy of newly developed models such as the study of Onyeiwu (2009); Wang \& Campbell (2010); Kiyak \& Labanauskaite (2012); Mamo (2011) and Soon et al. (2014). The third category deals with an applied investigation or studies which aim to tell the bankruptcy status of particular firms in a given country like the study of Mohammed \& Soon (2012); Kenneth \& Adeniyi (2014) and Azadinamin (2012). This study assumed the nature of the third category where the Altman revised model, Taffler (1983) and Beneish (1999) model is applied to assess the bankruptcy status and financial statement fraud of non-failed commercial banks in Ghana.

\subsection{Empirical Review}

A number of studies have materialized to explicate corporate bankruptcy and the ability of predictive models in successfully predicting their occurrence. This section offers insight into the pieces of literature and models for forecasting business insolvency and manipulation of annual financial accounts.

A study by Altman [1968], identified some financial KPIs - working capital, total assets, earnings and retained earnings before interest and tax, the market value of equity, the book value of total debt and sales. These KPIs are considered important in comparing companies in a data set of 33 failed and 33 non-failed companies. Altman's five -variable model identified 95 percent of the total sample of companies tested for bankruptcy. This percentage rate of success in predicting bankruptcy fell to 72 percent when the data used was obtained two years prior to bankruptcy. This study came out with a model that is called (Z-Score) which has received overwhelming endorsement across the globe. It also measures the firm's longevity, liquidity, profitability, leverage, productivity, and solvency, leads to best-known conclusions, reliability and avoids judgment bias according to [Sulphey, 2013].

Oware, Samanhyia, and Anisom-Yaansah [2016] studied financial bankruptcy and bankruptcy prediction in Ghanaian selected listed banks. Using Altman's Z-score model, they found out that, individually, $80 \%$ of the selected banks have their average Z-score between 1.1 to 2.6 and are classified in the grey zone. These banks were found to be neither financially bankrupt nor classified as safe. On the other hand, $20 \%$ of the selected banks have been found to be in the bankrupt zone.

Bhunia et al. [2011] argued that protective measures can be taken if the company is predicted to be proceeding in the direction of potential bankruptcy and this can help ease the financial crisis to all stakeholders and minimizes the bankruptcy cost. However, they argued that resolve bankruptcy problem may result in a conflict of interest between shareholders (who want the company to invest risky but high return projects so that the value of the firm will rise) and creditors (who require low-risk projects since it leaves them with a low value).

Soon et al. [2014] used Altman's Z score model to predict the financial bankruptcy of 28 firms listed on services sector at the stock exchange of Malaysia from 2003 to 2009, and this study concluded that Z score model can be used to differentiate between failure companies and non-failure companies, and this model is very useful for investors to expect financial failure of any companies.

Chotalia [2014] examined the financial health of Indian private sector banks using Altman's Z-score model and concluded that banks of the private sector understudy fell in 'Grey Zone' as per Z-score criteria and the risk of financial bankruptcy was looming on selected banks.

Zeytınoglu and Akarim [2013] used Altman's Z-score model to calculate 20 financial ratios to predict the bankruptcy of companies and developed the most reliable model by analyzing these ratios statistically. The study found capital adequacy and networking capital/ total assets ratios are deemed to be significant ratios in the three periods covered [2009-2011].

Usdin and Bloom [2012] recommended that the use of experts who are independent of the pressures inherent in managing a company and are available to analyze and advise a company in any difficult financial situations. 
Such professionals include Attorneys specializing in advising bankrupt companies, Accountants specializing in assisting bankrupt companies and Turnaround specialists.

Nzewi, Ezejiofor, and Okoye [2014] used Altman's Z-score model to predict the bankruptcy of Nigerian banks. This study concluded that the model was capable of determining truthfully the failure potential of sound and healthy banks. Furthermore, this research showed that Altman's bankruptcy prediction model could have successfully predicted the collapse of the banks that eventually suffered a corporate failure in Nigeria. And also the study of Adeyemi [2011] identified lack of transparency, inadequate capital huge and non-performing loans as accountable for bank failure in Nigeria. In addition, factors such as ownership structure, poor management, and weak internal control system may be a cause for failure.

Al-Khatib and Al-Horani [2012] used Logistic Regression and Discriminant Analysis and made a comparison between the two models to determine which is more relevant to be used, as well as which financial ratios are statistically significant in expecting the financial bankruptcy of Jordanian companies.

Jyothi and Veni [2018] conducted a comparative study of financial stability and solvency of four Indian private banks using Altman's Z-score model. The results of this study found that all four selected banks were financially robust and far away from bankruptcy. And also this study demonstrated that the Altman's Z-score value of all selected banks lied in Safe Zone since the Z-score was greater than 2.6.

Forecasting of corporate failure or insolvency has been well exploited using higher-income economic data such as the study of [Altman 1968, Taffler 1983, Boritz, Kennedy, \&Sun 2007]. Despite the multiplicity of the models available, corporations and scholars often make use of Altman [1968] and Taffler [1983] model hand in hand to predict business failure. Most of these studies successfully predicted corporate failure using the Altman MDA model. However, there are a number of limitations. There has been limited literature from emerging economy particularly Ghana whose economy is vulnerable to infrastructural interference. Also, findings from these studies failed to provide a suitable model to be used to achieve consistent results in predicting corporate failure. This paper, therefore, applies Altman [1968], Taffler [1983], and Beneish's [1999] model to fill this gap by adding literature evidence from an emerging economy perspective by statistically assessing the insolvency status of commercial banks in Ghana. Altman and Taffler's model is used to determine the bankruptcy status whereas the Beneish model is used to examine the accuracy of the annual financial statement published by the understudy banks.

2.2.1 Theoretical Review-Altman's [2000] Z-Score (Model 1). $\operatorname{ALTMAN}(Z)=0.717 X 1+0.847 X 2+3.107 X 3+0.420 X 4+0.998 X 5$

This model was developed by Professor Edward Altman in the year 2000. The original Altman Z-score was later modified to overcome this shortcoming, and now the Altman Z-score model can be used for both manufacturing and non-manufacturing, private companies and for those listed on the emerging markets. The model, for some reason, appears to create a lot of mixed emotions; some of these emotions are in favor of it while others are against it. The study of Grice and Ingram [2001] indicated that the accuracy of the Altman Z-score model is significantly lower in recent periods than reported in Altman's study. Most criticisms against this model are its over-reliance on accounting data; focus on failure rather than sustainability of the business; inadequate recognition of cash-flow as a relevant component; lack of consideration on non-financial ratios; the need for industry-specific or geography-specific model types and the danger of flexible interpretation or manipulation of financial results resulting in "window dressing" or inappropriate favorable report of financial position [Wilkinson, 2009]. The first shortcoming of the Altman Z-score model is the need for industry-specific or geography-specific model types. Specific industries have different characteristics; hence it would not be suitable to apply a general model for all these industries. And this model is the assumption that financial ratios are taken from public financial information will be accurate. According to Panneerselvam, [2008]. Firms in financial bankruptcy manipulate their financial statements to show good performance. Therefore, errors in these secondary data will influence the level of accuracy of the outcomes and will not be suitable for the present purpose. The interpretation of the Zscore as presented by Professor Altman's theory indicates that overall Score more than 2.9 represents a zone of creditworthiness or financial soundness. However, a score below 1.23 is classified as an insolvency or liquidation zone (Failed zone). Finally, the gap between 1.23 and 2.9 is the Zone of Ignorance or uncertainty.

$$
X 1=\frac{\text { WorkingCapital }}{\text { TotalAsset }}
$$

The working capital is ascertained by subtracting current liabilities from the current asset. This matrix of $\mathrm{X}_{1}$ is used to estimates the net liquid asset as a ratio of the total book value of identifiable assets. In the ideal situation, continuous operating losses can lead to a deterioration of current assets with respect to total Assets.

$$
X 2=\frac{\text { Accumulated } \operatorname{Pr} \text { ofit }}{\text { TotalAsset }}
$$

The matrix $\mathrm{X}_{2}$ measures the firm-level leverage and it embodies the reinvest profit into the asset. The logic 
behind $\mathrm{X}_{2}$ is that the accumulated profit of a firm is subject or prone to falsifications because of the reorganization and disbursement of dividends.

$$
X 3=\frac{\text { Operating Pr } o f i t}{\text { TotalAsset }}
$$

The relation $\left(\mathrm{X}_{3}\right)$ examines the efficient utilization of assets in creating of worth. A lower ratio is an indication of inefficiency in the utilization of the company's assets. The ratio, therefore, produces the cash available for creditors settlement, Government and shareholder's payments.

$$
X 4=\frac{\text { BookValueOfEquity }}{\text { BookValueOfLiabilities }}
$$

The book value of equity is calculated by adding the book value of ordinary and preference shares whereas the book value of total debts is estimated as either the addition of current and non-current debt or the total of longterm debts. The variable $\mathrm{X}_{4}$ is the reversal of the equity ratio.

$$
X 5=\frac{\text { Total Re venue }}{\text { TotalAsset }}
$$

This is the ratio that defines the activity of sales and assets. This ratio is used to assess the ability of asset in generating profit or earnings. Though the impact of $\mathrm{X}_{5}$ was underscored by Altman $(2000)$ however, it's inclusion will enhance the predictive ability of the Model.

\subsubsection{Taffler [1983] Z-Score (Model 2).}

Professor Taffler in 1983 suggested in his studies that failure models should reflect certain key variables of corporate solvency and performance such as profitability, working capital adequacy, financial risk, and liquidity. He thus formulated his Z-score as:

$\mathrm{Z}=0.53 \mathrm{X} 1+0.13 \mathrm{X} 2+0.18 \mathrm{X} 3+0.16 \mathrm{X} 4$

Where:

$$
\begin{aligned}
& X 1=\frac{\text { Profit Before Tax }}{\text { Current Liability }} \\
& X 2=\frac{\text { Current Asset }}{\text { Current Liability }} \\
& X 3=\frac{\text { Current Liability }}{\text { Total Asset }} \\
& X 3=\frac{\text { Quick Asset }- \text { Current Liability }}{\text { Operating Cost }- \text { Depreciation }}
\end{aligned}
$$

The weight $\mathbf{X}_{1}, \mathbf{x} 2, \mathbf{X}_{3}$, and $X_{4}$ in the model are the explanatory variables employed to estimates the explained variable (Z- Value) in the model. $\mathbf{X}_{\mathbf{1}}$ represents a measure of profitability, $\mathbf{X}_{\mathbf{2}}$ is a measure of working capital position, $\mathbf{X}_{3}$, on the other hand, is a measure of financial risk and finally, $\mathbf{X}_{\mathbf{4}}$ denotes the number of credit intervals. The benchmark for Taffler's model is subjected to Negative (-) and positive (+). A negative (-) score means the company has a financial profile similar to the previously failed business. While a positive $(+)$ score indicates the company is safe from insolvency risk.

\subsubsection{Beneish 1999 M-Score (Model 3)}

Professor Beneish developed a model called (M-score) in 1999 as a balancing scientific tool to the Altman Zscore model with the aim of protecting shareholders, creditors, and bankers in their evaluations. Beneish M-score model is considered a material tool that is frequently used to detect areas of possible manipulation on the firm's financial statements by accountants, auditors, and regulators (particularly the SEC). The Beneish model evaluates the possibility of earnings manipulation and also estimates the extent to which reported earnings to deviate from actual. Accounting manipulations include inter alia: reducing liabilities, recording revenue too soon and not recognizing current expense appropriately, increment in receivables, declining resource quality, development in sales and accruals [Warshavsky, 2012]. This model is used to discriminate between companies that have manipulated their annual financials. The score can be determined from eight independent variables and an intercept to detect whether the company's earnings have been manipulated by management. The eight variables were taken from the firm's financial statements and used to determine the M-score of this study. When an Mscore is greater than -2.22 indicates that the firm's financial statements may have been manipulated [Warshavsky, 2012]. Hence, if this score that is obtained from the computation of the eight variables from understudy bank's financials is greater than the cut-off point of negative 2.22 , then it concludes that the financial statements were manipulated. The score suggests that the financial statements are prepared by management should be examined 
or have to be investigated further for financial fraud. M-score model is considered as a probability model, and such cannot detect $100 \%$ manipulation. Beneish concluded that it is possible to determine $76 \%$ manipulators accurately and $17.5 \%$ incorrectly is considered as non-manipulator. According to Beneish et.al.[1999], the indices have varying rationales as described below.

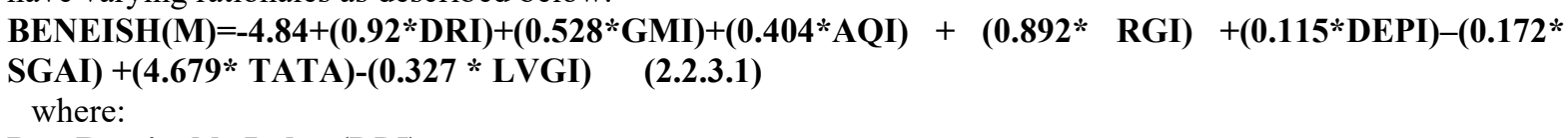

DRI can be used to measure the variations in respect of receivables consistent with the variations in respect of revenue. When a DRI score is 1.031 or below shows that the financial statements in respect of the DRI were not manipulated but 1.465 score or above indicates the financial statements have been manipulated in respect of the DRI or an indication that, the firm has changed its credit terms and now providing more credit than before. When this does not show a fair consistent trend then it suggests that either the majority of revenue is on credit terms rather than cash or the company has difficulty in the collection of cash from debtors. A rising DRI may be the perfect legal activity of the firm extending more credit to customers and the firms that overstated revenue. Therefore, a sharp rise in the DRI score provides signals to auditors that, the financial statements of the firms are manipulated or terms of credit have changed. Empirically described as:

$$
D R I=\frac{\text { ACCOUNT RECEIVABLE(CY)/SALES(CY) }}{\text { ACCOUNT RECEIVABLE }(\mathrm{PY}) / \operatorname{SALES}(\mathrm{PY})}
$$

\section{Gross Margin Index (GMI)}

GMI also can be used to measure the ratio of a preceding year's GMI to that of the contemporary year review. According to Harrington, [2005], the GMI score of 1.041 or lower suggests gross profit of the current period is not manipulated however a score of 1.193 is an indication that gross profit of the firm is manipulated. Financial Analyst orated that earning quality is considered a very important aspect for assessing the firm's financial fitness and therefore, can create an avenue for earnings manipulations especially when performance is downgraded. The numerical representation is shown below.

$$
G M I=\frac{\text { Sales }(\mathrm{PY})-\text { Cost oF Sales }(\mathrm{PY}) / \operatorname{Sales}(\mathrm{PY})}{\text { Sales }(\mathrm{CY})-\text { Cost oF Sales }(\mathrm{CY}) / \operatorname{Sales}(\mathrm{CY})}
$$

Asset Quality Index (AQI)

AQI is used to measure the percentage of total assets of the current year to the preceding year. According to Pustylnick (2009), a ratio greater than 1.0 is a signal that some overheads or intangible assets have been capitalized and others have been overdue for the impending year. Harrington 2005, espouse that growth in AQI suggests additional expenses have been capitalized to avoid writing-off to the comprehensive income statement in order to preserve profit. This can be mathematically presented as follows:

$$
A Q I=\frac{\text { Total Asset }- \text { PPE(cy)/Total Asset(cy) }}{\text { Total Asset }- \text { PPE(Py)/Total Asset(Py) }}
$$

\section{Revenue Growth Index (RGI)}

RGI is a measure of sales or revenue for the current year over the sales or revenue of the preceding year. And also can be used to measure the revenue figure in the contemporary year. Benchmark value of 1.134 or below forecast non-manipulation and a value above 1.607 predicts the possibility of sales or revenue manipulations. Harrington [2005] noted that firms with high growth rates find themselves highly motivated to commit fraud when the trends reverse. Below is the mathematical representation;

$$
R G I=\frac{\operatorname{Revenue}(\mathrm{cy})}{\operatorname{Revenue}(\mathrm{py})}
$$

\section{Depreciation Index (DEPI)}

DEPI is used to measure the ratio of the depreciation expense against the firm's value of PPE in the current year against that of the preceding year. DEPI ratio of 1.001 or lower is an indication of DEPI manipulations. However, a score above 1.077 indicates the value of the assets has been revalued or the useful life of the assets has been adjusted upward [Beneish, 1999]. The ratio is described as follows:

$$
D E P I=\frac{\text { Depreciation. } \exp (\mathrm{cy}) / \text { Depreciation. } \exp +\mathrm{PPE}(\mathrm{cy})}{\text { Depreciation. } \exp (\mathrm{py}) / \text { Depreciation. } \exp +\mathrm{PPE}(\mathrm{py})}
$$

Sales, General, and Administrative Expenses Index (SGAI)

SGAI is the ratio of sales, general and administrative expenses for the current year over the preceding year. When a score of 1.001 or below is obtained, it indicates that SGAI has not been manipulated. According to Thiagarajan and Lev. [1993], a disproportional increase in SGAI is considered as an indicator of a negative signal about the 
firm's upcoming prospects. A positive relation gives an indication of possible manipulations.

$$
S G A I=\frac{\text { Sales, General and Administrative Cost (cy )/Sales (cy) }}{\text { Sales, General and Administrative Cost (py )/Sales (py) }}
$$

\section{Leverage Index (LEVI)}

LEVI can be used to measure the firm's ratio in terms of total debt to total assets for the current year is divided over the preceding year's ratio. When a LEVI is greater than 1 indicates that there is an increase in leverage position in the firm and that the firm has taken more debt to operate or to run the business for the period under review. Empirically;

$$
\text { LEVI }=\frac{\text { TotalLiability }}{\text { TotalAsset }}
$$

\section{Total Accruals to Total Assets Index (TATAI)}

TATAI is the ratio of change in working capital other than cash and less depreciation. The increase in TATAI may indicate that goodwill and amortization numbers in the financial statements of the company have been tampered with. When a mean score is 0.018 indicates that there are non-financial manipulations in respect of TATAI while a mean score of 0.031 and above is an indicator that the financial data have been tampered with. Mathematically presented as:

$$
T A T A I=\frac{\text { Working Capital }- \text { Depreciation }}{\text { TotalAsset }}
$$

\subsection{Methodology}

\section{1 sample and Research Method}

The study uses numerical investigation on the dataset extracted from the financial position, and comprehensive income statement of quoted and Unquoted commercial banks situated in Ghana. The financial statements were taken from the website of the companies, Ghana Stock Exchange(GSE) and Annual Report Ghana. The study sampled a total of 19 commercial banks within the categories of multinational and local banks based on the availability of up to date financial statements on the above-mentioned websites. The time spinning from 2015 to 2018 was the period covered by the study and it is considered long enough to detect any financial or insolvency risk. The selection of the banking sector was purposively considered by the authors due to the current instability and inefficiency in the Ghanaian banking sector. The study adopted three (3) models for the detection of potential bankruptcy signs and earnings manipulations. Altman [2000] Z-Score and Taffler [1983] Z-Score model was applied for the detection and establishment of the financial soundness of the banks under review. The Beneish MScore model was employed to investigates the possibility of earnings Manipulations for the understudy years. The investigative tools adopted for this study include excel for the computations of variables, Z-Scores, and M-score and Eviews version ten for descriptive and correlation analysis.

\subsection{Hypotheses.}

Considering the recent occurrences of mergers and acquisitions, liquidation and closure of some prominent commercial banks in Ghana between 2016 and 2019 such as UT bank, UniBank, Construction bank, Beige bank, Royal Bank, Capital Bank, as well as the proposed merger and acquisition deal between Energy Bank and First National bank (BOG annual report 2018) indicated that the Ghanaian Banking sector is experiencing credit crunch. Also taking into account the recent minimum capital requirement set by the Bank of Ghana (BOG) which every registered Commercial Bank is required to meet as of 2018 is likely to motivate some banks to manipulate their earning to fake their true performance. This assumption is supported by the study of Macarthy [2017], Gyarteng [2014], and Beneish [1999] which concluded that financial ratios taken from public financial information will not be accurate considering the fact that firms with financial distress manipulate their financials to show healthier performance as in the case of Enron Corporation. Consequently, manipulations in these financial data will affect the level of accuracy of the outcomes and will not be appropriate for the failure prediction [Panneerselvam, 2008]. Therefore, this study seeks to test the following hypotheses:

$\mathbf{H}_{1}$. The more financially troubled commercial banks have the lowest Z-Score ratio using both Altman and Taffler models for the years under review.

$\mathbf{H}_{2}$. The understudied banks that are less financially troubled have the highest Z-Score ratio under the study period using the Altman and Taffler model.

$\mathbf{H}_{3}$ : The annual financial statements published by the commercial banks is likely to exhibit signs of manipulations to show better performance.

H4: The annual financial statements published by the commercial banks were not manipulated to show better performance. 


\section{Empirical Results \\ 4.1 Descriptive Statistics}

The descriptive statistics of financial ratios (independents variables) computed using the four-year annual financial statements for all the models are summarized in table1. Similarly, the descriptive statistics of 19 commercial banks that were computed by means of Altman Z-Score, Taffler Z-score, and Beneish M-score models are displayed in tables 2, 3 and 4 respectively. Table 1 is divided into three namely, Altman, Taffler and Beneish model.

From table 1: The highest mean of financial ratio (3.170) in the case of Altman was recorded by Sales/Total asset (x5) with a corresponding maximum value of $\mathbf{8 . 9 7 0}$ for a total sample of 19 banks and this is consistent with the result of Sulub, S. A. [2014]. This result indicates that the ability of asset in generating earnings is promising among the 19 selected banks. However, the firm-level leverage matrix (x2) recorded the lowest mean score $\mathbf{( \mathbf { 0 . 0 4 1 } )}$ with a maximum value of (0.682) for all understudy banks. In the case of the Taffler model, the number of credit/defense intervals $(\mathrm{x} 4)$ recorded the highest mean score of 2.565 with a maximum mean of 11.741. This implies the commercial banks on average can meet their expenses for approximately 3 years if it is unable to record revenue. This is followed by the working capital ratio (x2), financial risk ratio (x3) and lastly profitability ratio with a mean value of $\mathbf{0 . 2 3 3}$. Beneish model, on the other hand, recorded the highest variable mean score value of 3.493 with a maximum of $\mathbf{1 4 4 . 3 4 8}$ and this score is attributed to General and administration expenses index (SGAI). This depicts a high probability of SGAI manipulation followed by DEPI, and TATAI with a mean of $\mathbf{1 . 2 9 7}$ and 0.170 respectively. According to Balmer M. G Principles of statistics, a distribution is said to be normal if the value of the skewness and kurtosis are respectively 0 and 3. From Table 1, it can be seen that the value of skewness and kurtosis of the variables indicates a Leptokurtic distribution.

From Table 2 it can be observed from the Altman model that the mean Z-score of the 19 commercial banks chronicled a maximum value of 9.4630 in 2018 and a minimum value of 0.9002 in 2015 . With the exception of the year 2018, the mean Z-score recorded the least value of 3.2095 in 2015 and this observation could possibly mean the commercial banks were financially not healthy in the year 2015 as compared to the remaining years under review.

The Taffler Z-Scores as presented in table 3 chronicled a maximum Z-score of 4.000 in 2016 and a minimum of -0.9780 in 2018. Similar to observation in Altman result, the mean z- score recorded the least value 0.7841 in 2015 followed by 2017 then 2016 and the highest mean were recorded in 2018 and this result may indicate a sign of financial distressed among the commercial banks in the year 2015 according to Taffler Z- scores and this observation is consistent with that of Altman model (see table 2 above). In the case of Beneish M-score (see table 4), reported a maximum mean M-Score of 24.6450 in 2015 and a minimum of -37.4360 in 2015. However, the mean M-Score registered a peak value of -0.6659 in 2018 and the lowest value of -2.6604 in 2015 . This result showcases a clear incident of higher earnings manipulations in $\mathbf{2 0 1 8}$ among the sampled commercial banks. 
Table 1: Descriptive statistics for 19 sampled Banks using the annual financial report for the period of 4 years to 2018.

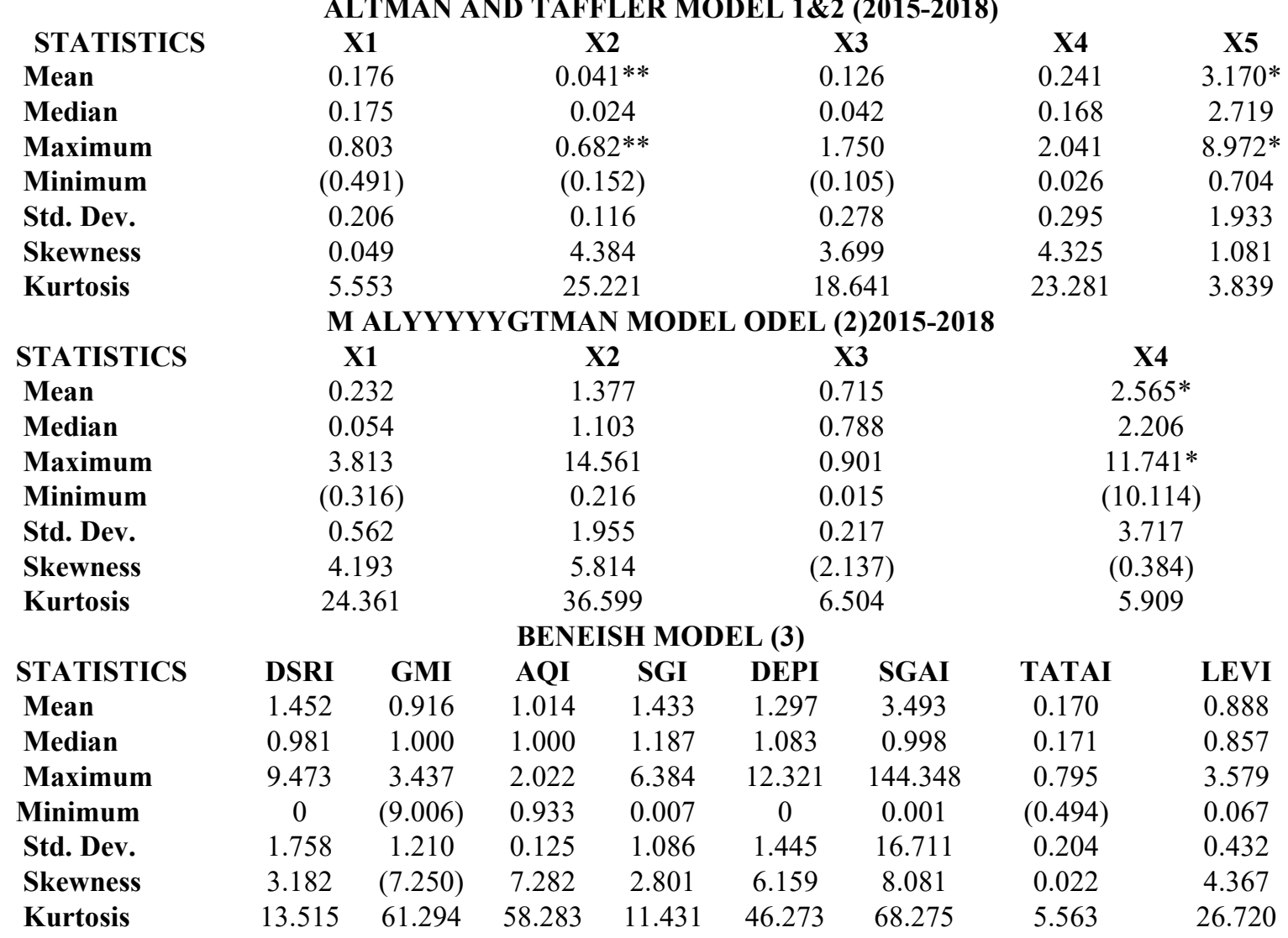

Source: Financial Reports (2015 - 2018)

Table 2: Descriptive statistics (Z-SCORES Model 1) ALTMAN (2000) Z-SCORE, $N=19$

\begin{tabular}{cccccccc}
\hline & MEAN & MEDIAN & MINIMUM & MAXIMUM & Std.Dev. & SKEWNESS & KURTOSIS \\
\hline 2015 & 3.2095 & 2.5500 & 0.9002 & 8.5750 & 2.1218 & 1.1847 & 3.5121 \\
2016 & 3.5711 & 3.6940 & 1.6580 & 5.9580 & 1.3178 & 0.2544 & 1.9925 \\
2017 & 3.9850 & 3.5220 & 1.8460 & 8.8100 & 1.7302 & 1.2180 & 4.3047 \\
2018 & 4.4927 & 3.9010 & 2.2930 & 9.4630 & 1.9235 & 1.2759 & 3.7836 \\
\hline
\end{tabular}

Source: Financial Reports (2015 - 2018)

Table 3: Descriptive Statistics (Taffler Z-Scores, Model 2).

TAFFLER (1983) Z-SCORE, $N=19$

\begin{tabular}{cccccccc}
\hline & MEAN & MEDIAN & MINIMUM & MAXIMUM & Std.Dev. & SKEWNESS & KURTOSIS \\
\hline 2015 & 0.7841 & 0.6380 & $(0.7060)$ & 2.3820 & 0.7174 & 0.5561 & 3.4114 \\
2016 & 0.8637 & 0.6250 & $(0.2700)$ & 4.0000 & 0.8982 & 2.3994 & 9.0535 \\
2017 & 0.7849 & 0.7530 & $(0.9060)$ & 2.1910 & 0.6399 & $(0.1649)$ & 4.8765 \\
2018 & 0.9311 & 0.8560 & $(0.9780)$ & 2.2840 & 0.6623 & $(0.7521)$ & 5.4296 \\
\hline
\end{tabular}

Source: Source: Financial Reports (2015 - 2018)

Table 4: Descriptive Statistics (Beneish M-Score, Model 3).

BENEISH (1999) M-SCORE, $N=19$

\begin{tabular}{cccccccc}
\hline & MEAN & MEDIAN & MINIMUM & MAXIMUM & Std.Dev. & SKEWNESS & KURTOSIS \\
\hline 2015 & $(2.6604)$ & $(1.4820)$ & $(37.4360)$ & 24.6450 & 12.1550 & $(0.9072)$ & 5.8184 \\
2016 & $(1.6002)$ & $(1.4520)$ & $(8.1380)$ & 1.3150 & 2.3771 & $(1.5177)$ & 4.9545 \\
2017 & $(1.3609)$ & $(1.5890)$ & $(12.1620)$ & 10.7190 & 4.1161 & 0.5014 & 7.2876 \\
2018 & $(0.6659)$ & $(1.0410)$ & $(5.5080)$ & 7.1720 & 2.6207 & 1.0557 & 5.8786 \\
\hline
\end{tabular}

Source: Financial Reports (2015 - 2018) 


\subsection{Correlation Matrix analysis.}

\subsubsection{Correlation of the independent variables to the $\mathrm{Z}$-Scores}

The correlation of the independent variables to the Z-Scores basically advocates what variables or ratios are the main drivers of the Z-score. Therefore, knowing the main drivers of the Z-score, organizations can enhance those ratios or variables to effect the better performance of the organization. The Altman Model (table 5) showed a strong correlation between X5 and Z- Score, signifying that a high asset turnover ratio was a significant driver in the survival of the business. Except for working capital/Total asset (x1) which showed a negative correlation with the Z-Score, the remaining ratios $\mathrm{x} 2, \mathrm{x} 3$, and $\mathrm{x} 4$ indicated a weak positive correlation with the Z-Score (see table 20 below). With regards to Taffler's model, credit or defense interval (x4) registered a strong positive correlation with the Z-Score indicating that credit interval is the major determinant of business survival. However, with the exception of the financial risk ratio (x3), the remaining ratios (profitability and working capital position) indicated a weak positive correlation with the Z-Score (see table 6).

To conclude, there was a significant correlation between all the variables and the Z-Scores in both Altman and Taffler model, whilst there was a strong correlation between credit interval ratio and Z-Score in Taffler's model and asset turnover ratio and the Z-score in the case of Altman model.

Table 5: Correlation matrix between the independent variables and the Z-scores (Altman-Model)

\begin{tabular}{ccccccc}
\hline & $\mathbf{X 1}$ & $\mathbf{X 2}$ & $\mathbf{X 3}$ & $\mathbf{X 5}$ & $\mathbf{X 4}$ & $\mathbf{Z S C O R E}$ \\
$\mathbf{X 1}$ & 1.0000 & 0.1719 & $(0.2150)$ & $(0.0340)$ & $(0.0899)$ & $(0.0168)$ \\
$\mathbf{X 2}$ & 0.1719 & 1.0000 & 0.0225 & $(0.0389)$ & 0.0892 & 0.0267 \\
$\mathbf{X 3}$ & $(0.2150)$ & 0.0225 & 1.0000 & $(0.2954)$ & $(0.0256)$ & 0.1314 \\
$\mathbf{X 5}$ & $(0.0340)$ & $(0.0389)$ & $(0.2954)$ & 1.0000 & 0.1005 & 0.8997 \\
$\mathbf{X}$ & $(0.0899)$ & 0.0892 & $(0.0256)$ & 0.1005 & 1.0000 & 0.0872 \\
$\mathbf{Z}$ & $(0.0168)$ & 0.0267 & 0.1314 & 0.8997 & 0.0872 & 1.0000 \\
\hline
\end{tabular}

Table 6: Correlation matrix between the independent variables and the Z-scores (Taffler-Model 2)

\begin{tabular}{cccccc}
\hline & $\mathbf{X 1}$ & $\mathbf{X 2}$ & $\mathbf{X 3}$ & $\mathbf{X 4}$ & $\mathbf{Z S C O R E}$ \\
\hline $\mathbf{X 1}$ & 1.0000 & $(0.1086)$ & $(0.3336)$ & 0.1430 & 0.4727 \\
$\mathbf{X 2}$ & $(0.1086)$ & 1.0000 & 0.0846 & 0.0262 & 0.3323 \\
$\mathbf{X 3}$ & $(0.3336)$ & 0.0846 & 1.0000 & $(0.4328)$ & $(0.4091)$ \\
$\mathbf{X} 4$ & 0.1430 & 0.0262 & $(0.4328)$ & 1.0000 & 0.8658 \\
$\mathbf{Z}$ & 0.4727 & 0.3323 & $(0.4091)$ & 0.8658 & 1.0000 \\
\hline
\end{tabular}

Source: Financial Reports (2015 - 2018)

4.2.2 Correlation matrix of the Z-scores (Altman and Taffler) to Beneish M-Score

The logic of knowing the correlation between Z-Scores and Beneish M-Score will go a long way to assist scholars and management in decision making. To scholars, it will give reasons for the need to use both models in Corporate failure predicting studies. Management, shareholders, auditors, and investors on the other hand' will appreciate the importance of using Altman and Taffler's model to assess the performance of corporate entities. As reported in Table 21 below, it can be observed that there is a strong positive correlation between Beneish M-Score and all the Z-Scores models employed in this study (Altman 2000 and Taffler 1983 model). Note, the fact there is such a strong and positive correlation between the models serves as a reasonability check, as an increase in M-Score advocate possibility of earning manipulations. Hence, a positive correlation suggests that the banks under review tend to manipulate their financial statements to showcases a good performance. Therefore, as the banks manipulate their earnings (upwards M-Score), Altman and Taffler's Z-Scores improve from distress to safe zone. Also, the negative correlation between Taffler and Altman Z-Scores indicates that as the banks obtained better Z-Score in Taffler's model, their score in the Altman model tends to be worsening and this accounted for the differences in their predictive accuracy (see table 7). 
Table 7: Correlation matrix of the Z-scores (Altman and Taffler) to Beneish M-Score

\begin{tabular}{lccc}
\hline & TAFFLER Z-SCORE & ALTMAN Z-SCORE & BENEISH M-SCORE \\
\hline TAFFLER Z-SCORE & 1.0000 & $(0.1777)$ & 0.7365 \\
ALTMAN Z-SCORE & $(0.1777)$ & 1.0000 & 0.4479 \\
BENEISH M-SCORE & 0.7365 & 0.4479 & 1.0000 \\
\hline
\end{tabular}

Source: Financial Reports (2015 - 2018)

4.3 Presentation and Assessments of Z-Scores.

Investigating the annual financials using Altman and Taffler Z-Scores provides justifications for appreciating and appraising the fallouts of business processes and illuminates how well the industry has performed. In this regard, Altman and Taffler's Z-Scores were employed to examine the bankruptcy status of 19 commercial banks in Ghana and the outcome is presented below.

Table 8: Results of Z-Score using Altman's (2000) Model (N=19)

\begin{tabular}{cccccc}
\hline BANK CODE & $\begin{array}{c}\mathbf{2 0 1 5} \\
\text { Z-SCORE }\end{array}$ & $\begin{array}{c}\mathbf{2 0 1 6} \\
\text { Z-SCORE }\end{array}$ & $\begin{array}{c}\mathbf{2 0 1 7} \\
\text { Z-SCORE }\end{array}$ & $\begin{array}{c}\mathbf{2 0 1 8} \\
\text { Z-SCORE }\end{array}$ & $\begin{array}{c}\text { AVERAGE } \\
\text { Z-SCORE }\end{array}$ \\
\hline ABG & 3.348 & 3.927 & 4.459 & 5.628 & 4.058 \\
ADB & 2.564 & 2.345 & 2.510 & 6.731 & 3.405 \\
BAB & 8.575 & 5.470 & 5.413 & 3.519 & 6.739 \\
BOA & 2.046 & 4.656 & 4.946 & 3.901 & 4.084 \\
CALL & 3.022 & 2.290 & 3.322 & 3.304 & 3.091 \\
EGH & 5.619 & 5.958 & 8.810 & 8.193 & 6.559 \\
FAB & 1.431 & 4.947 & 6.788 & 3.025 & 3.736 \\
FBL & 4.117 & 3.694 & 3.100 & 2.794 & 3.608 \\
FNB & 2.156 & 1.658 & 2.756 & 2.293 & 2.000 \\
GCB & 2.414 & 3.216 & 2.256 & 3.091 & 2.749 \\
GTB & 5.407 & 4.075 & 3.522 & 9.463 & 5.613 \\
RBG & 1.229 & 3.862 & 4.873 & 4.670 & 3.263 \\
SBG & 1.643 & 2.147 & 4.554 & 4.324 & 2.948 \\
SCB & 7.167 & 5.551 & 4.278 & 4.007 & 5.389 \\
SOGEGH & 1.690 & 1.678 & 2.821 & 3.185 & 2.305 \\
TBL & 1.311 & 2.603 & 2.583 & 3.885 & 2.361 \\
UBA & 3.792 & 2.924 & 4.376 & 6.054 & 4.572 \\
UMB & 0.900 & 3.947 & 1.846 & 4.390 & 3.261 \\
ZTB & 2.550 & 2.902 & 2.502 & 2.903 & 2.253 \\
\hline
\end{tabular}

Source: Financial Reports (2015 - 2018).

Table 9: Results of Z-Score using Taffler (1983) Z-Score Model (N=19)

\begin{tabular}{cccccc}
\hline BANK CODE & $\begin{array}{c}\mathbf{2 0 1 5} \\
\text { Z-SCORE }\end{array}$ & $\begin{array}{c}\mathbf{2 0 1 6} \\
\text { Z-SCORE }\end{array}$ & $\begin{array}{c}\mathbf{2 0 1 7} \\
\text { Z-SCORE }\end{array}$ & $\begin{array}{c}\mathbf{2 0 1 8} \\
\text { Z-SCORE }\end{array}$ & $\begin{array}{c}\text { AVERAGE } \\
\text { Z-SCORE }\end{array}$ \\
\hline ABG & 2.045 & 0.589 & 0.589 & 1.916 & 2.284 \\
ADB & 1.744 & 1.867 & 0.665 & 0.788 & 1.886 \\
BAB & 0.698 & 0.603 & 0.772 & 0.879 & 0.856 \\
BOA & 1.056 & 1.868 & 0.531 & 0.779 & 0.853 \\
CALL & 1.395 & 0.753 & 0.472 & 0.667 & 0.752 \\
EGH & 0.418 & 0.432 & 0.568 & 0.523 & 0.609 \\
FAB & 1.329 & 0.097 & 0.489 & 0.358 & 0.642 \\
FBL & 0.875 & 0.680 & 0.561 & 0.753 & 1.143 \\
FNB & 2.594 & 0.666 & 0.796 & 0.552 & 1.217 \\
GCB & 0.664 & 0.674 & 0.701 & 0.699 & 0.595 \\
GTB & 1.505 & 1.746 & 1.731 & 2.191 & 1.402 \\
RBG & 0.795 & 0.501 & 0.328 & 0.513 & 0.774 \\
SBG & 0.591 & 0.603 & 0.701 & 1.192 & 1.087 \\
SCB & 0.856 & 0.756 & 1.051 & 1.020 & 1.052 \\
SOGEGH & 0.781 & 0.638 & 0.625 & 0.536 & 0.740 \\
TBL & 0.310 & 0.229 & 0.204 & 0.220 & 0.238 \\
UBA & 0.710 & $(0.706)$ & 4.000 & 1.223 & 1.332 \\
UMB & 1.114 & 2.382 & 1.897 & 1.010 & 1.207 \\
ZTB & 1.481 & 0.520 & $(0.270)$ & $(0.906)$ & $(0.978)$ \\
\hline
\end{tabular}

Source: Financial Reports (2015-2018). 
Table 10: Assessment of Banks correctly classified as creditworthiness using Altman z-Scores on a yearly

\begin{tabular}{|c|c|c|c|c|c|c|c|c|}
\hline & \multicolumn{2}{|c|}{2015} & \multicolumn{2}{|c|}{2016} & \multicolumn{2}{|c|}{2017} & \multicolumn{2}{|c|}{2018} \\
\hline & $\begin{array}{l}\text { BANK } \\
\text { CODE }\end{array}$ & $\begin{array}{c}\text { Z- } \\
\text { SCORE }\end{array}$ & $\begin{array}{l}\text { BANK } \\
\text { CODE }\end{array}$ & $\begin{array}{c}\text { Z- } \\
\text { SCORE }\end{array}$ & $\begin{array}{l}\text { BANK } \\
\text { CODE }\end{array}$ & $\begin{array}{c}\text { Z- } \\
\text { SCORE }\end{array}$ & $\begin{array}{l}\text { BANK } \\
\text { CODE }\end{array}$ & $\begin{array}{c}\text { Z- } \\
\text { SCORE }\end{array}$ \\
\hline & $\mathrm{ABG}$ & 3.348 & $\mathrm{ABG}$ & 3.927 & UBA & 4.376 & $\mathrm{ABG}$ & 5.628 \\
\hline & $\mathrm{BAB}$ & 8.575 & BAB & 5.470 & SCB & 4.278 & $\mathrm{ADB}$ & 6.731 \\
\hline & CALL & 3.022 & $\mathrm{BOA}$ & 4.656 & SBG & 4.554 & BAB & 3.519 \\
\hline & EGH & 5.619 & EGH & 5.958 & RBG & 4.873 & BOA & 3.901 \\
\hline & FBL & 4.117 & FAB & 4.947 & GTB & 3.522 & CALL & 3.304 \\
\hline & GTB & 5.407 & FBL & 3.694 & FBL & 3.100 & EGH & 8.193 \\
\hline & SCB & 7.167 & GCB & 3.216 & FAB & 6.788 & FAB & 3.025 \\
\hline & UBA & 3.792 & GTB & 4.075 & EGH & 8.810 & GCB & 3.091 \\
\hline & & & RBG & 3.862 & CALL & 3.322 & GTB & 9.463 \\
\hline & & & $\mathrm{SCB}$ & 5.551 & $\mathrm{BOA}$ & 3.322 & $\mathrm{RBG}$ & 4.670 \\
\hline & & & UBA & 2.924 & $\mathrm{BAB}$ & 5.413 & SBG & 4.324 \\
\hline & & & UMB & 3.947 & $\mathrm{ABG}$ & 4.459 & SCB & 4.007 \\
\hline & & & ZTB & 2.902 & & & SOGEGH & 3.185 \\
\hline & & & & & & & TBL & 3.885 \\
\hline & & & & & & & UBA & 6.054 \\
\hline & & & & & & & UMB & 4.390 \\
\hline & & & & & & & ZTB & 2.903 \\
\hline Total Banks & \multicolumn{2}{|c|}{8} & \multicolumn{2}{|c|}{13} & \multicolumn{2}{|c|}{12} & \multicolumn{2}{|c|}{17} \\
\hline Percentage \% & \multicolumn{2}{|c|}{$42 \%$} & \multicolumn{2}{|c|}{$68 \%$} & \multicolumn{2}{|c|}{$63 \%$} & \multicolumn{2}{|c|}{$89 \%$} \\
\hline
\end{tabular}

Source: Financial Reports (2015-2018).

Table 11: Assessment of Non-Failed Banks classified as failed by Altman Z-score (Type II Error), N=19

\begin{tabular}{ccccccccc}
\hline & \multicolumn{2}{c}{2015} & \multicolumn{2}{c}{2016} & \multicolumn{2}{c}{2017} & \multicolumn{2}{c}{$\mathbf{2 0 1 8}$} \\
& BANK & Z- & BANK & Z- & BANK & Z- & BANK & \\
& CODE & SCORE & CODE & SCORE & CODE & SCORE & CODE & Z-SCORE \\
\cline { 2 - 9 } Total & UMB & 0.900 & NILL & NILL & NILL & NILL & NILL & NILL \\
Percentage $\%$ & & $\mathbf{1}$ & \multicolumn{2}{c}{ NILL } & \multicolumn{2}{c}{ NILL } & NILL \\
\hline
\end{tabular}


Table 12: Assessment of Banks correctly classified as creditworthiness using Taffler's z-Scores on a yearly

\begin{tabular}{|c|c|c|c|c|c|c|c|c|}
\hline & \multicolumn{2}{|c|}{2015} & \multicolumn{2}{|c|}{2016} & \multicolumn{2}{|c|}{2017} & \multicolumn{2}{|c|}{2018} \\
\hline & $\begin{array}{l}\text { BANK } \\
\text { CODE }\end{array}$ & $\begin{array}{c}\text { Z- } \\
\text { SCOR } \\
\text { E }\end{array}$ & $\begin{array}{l}\text { BANK } \\
\text { CODE }\end{array}$ & $\begin{array}{l}\text { Z- } \\
\text { SCOR } \\
\text { E }\end{array}$ & $\begin{array}{l}\text { BANK } \\
\text { CODE }\end{array}$ & $\begin{array}{l}\text { Z- } \\
\text { SCOR } \\
\text { E }\end{array}$ & $\begin{array}{l}\text { BANK } \\
\text { CODE }\end{array}$ & $\begin{array}{l}\text { Z- } \\
\text { SCOR } \\
\text { E }\end{array}$ \\
\hline & $\mathrm{ABG}$ & 2.045 & $\mathrm{ABG}$ & 0.589 & $\mathrm{ABG}$ & 0.589 & $\mathrm{ABG}$ & 1.916 \\
\hline & $\mathrm{ADB}$ & 1.744 & $\mathrm{ADB}$ & 1.867 & $\mathrm{ADB}$ & 0.665 & $\mathrm{ADB}$ & 0.788 \\
\hline & BAB & 0.698 & BAB & 0.603 & BAB & 0.772 & BAB & 0.879 \\
\hline & BOA & 1.056 & $\mathrm{BOA}$ & 1.868 & $\mathrm{BOA}$ & 0.531 & BOA & 0.779 \\
\hline & CALL & 1.395 & CALL & 0.753 & CALL & 0.472 & CALL & 0.667 \\
\hline & EGH & 0.418 & EGH & 0.432 & EGH & 0.568 & EGH & 0.523 \\
\hline & FAB & 1.329 & FAB & 0.097 & FAB & 0.489 & FAB & 0.358 \\
\hline & FBL & 0.875 & FBL & 0.680 & FBL & 0.561 & FBL & 0.753 \\
\hline & FNB & 2.594 & FNB & 0.666 & FNB & 0.796 & FNB & 0.552 \\
\hline & GCB & 0.664 & GCB & 0.674 & GCB & 0.701 & GCB & 0.699 \\
\hline & GTB & 1.505 & GTB & 1.746 & GTB & 1.731 & GTB & 2.191 \\
\hline & $\mathrm{RBG}$ & 0.795 & RBG & 0.501 & $\mathrm{RBG}$ & 0.328 & $\mathrm{RBG}$ & 0.513 \\
\hline & SBG & 0.591 & SBG & 0.603 & SBG & 0.701 & SBG & 1.192 \\
\hline & SCB & 0.856 & SCB & 0.756 & SCB & 1.051 & SCB & 1.020 \\
\hline & $\begin{array}{c}\text { SOGEG } \\
\mathrm{H}\end{array}$ & 0.781 & $\begin{array}{c}\text { SOGEG } \\
\mathrm{H}\end{array}$ & 0.638 & $\begin{array}{c}\text { SOGEG } \\
\mathrm{H}\end{array}$ & 0.625 & $\begin{array}{c}\text { SOGEG } \\
\mathrm{H}\end{array}$ & 0.536 \\
\hline & TBL & 0.310 & TBL & 0.229 & TBL & 0.204 & TBL & 0.220 \\
\hline & UBA & 0.710 & UMB & 2.382 & UBA & 4.000 & UBA & 1.223 \\
\hline & UMB & 1.114 & ZTB & 0.520 & UMB & 1.897 & UMB & 1.010 \\
\hline & ZTB & 1.481 & & & & & & \\
\hline Total Banks & \multicolumn{2}{|c|}{19} & \multicolumn{2}{|c|}{18} & \multicolumn{2}{|c|}{18} & \multicolumn{2}{|c|}{18} \\
\hline $\begin{array}{c}\text { Percentage } \\
\%\end{array}$ & \multicolumn{2}{|c|}{$100 \%$} & \multicolumn{2}{|c|}{$95 \%$} & \multicolumn{2}{|c|}{$95 \%$} & \multicolumn{2}{|c|}{$95 \%$} \\
\hline
\end{tabular}

Source: Financial Reports (2015-2018).

Table 13: Assessment of Non-Failed Banks classified as failed (Taffler), N=19 BANKS.

\begin{tabular}{|c|c|c|c|c|c|c|c|c|}
\hline & \multicolumn{2}{|c|}{2015} & \multicolumn{2}{|r|}{2016} & \multicolumn{2}{|c|}{2017} & \multicolumn{2}{|r|}{2018} \\
\hline & Bank & & Bank & & Bank & & Bank & \\
\hline & Code & Z-Score & Code & Z-Score & Code & Z-Score & Code & Z-Score \\
\hline & NILL & - & UBA & $(0.706)$ & ZTB & $(0.270)$ & ZTB & $(0.906)$ \\
\hline Total Banks & & NILL & & 1 & & 1 & & 1 \\
\hline Percentage \% & & NILL & & $5 \%$ & & $5 \%$ & & $5 \%$ \\
\hline
\end{tabular}

Table 14: Assessment of Banks correctly classified using Average Z-Scores (Altman model)

\begin{tabular}{|c|c|c|}
\hline Bank Code & Average Z-Score & Bank Status \\
\hline ABG & 4.058 & Quoted \\
\hline $\mathrm{ADB}$ & 3.405 & Quoted \\
\hline $\mathrm{BAB}$ & 6.739 & Unquoted \\
\hline $\mathrm{BOA}$ & 4.084 & Unquoted \\
\hline CALL & 3.091 & Quoted \\
\hline EGH & 6.559 & Quoted \\
\hline FAB & 3.736 & Unquoted \\
\hline FBL & 3.608 & Unquoted \\
\hline GTB & 5.613 & Unquoted \\
\hline RBG & 3.263 & Quoted \\
\hline SBG & 2.948 & Unquoted \\
\hline $\mathrm{SCB}$ & 5.389 & Quoted \\
\hline UBA & 4.572 & Unquoted \\
\hline UMB & 3.261 & Unquoted \\
\hline
\end{tabular}


Table 15: Assessment of Banks correctly classified using Average Z-Scores (Taffler model 2)

\begin{tabular}{ccc} 
Bank Code & Average Z-Score & Bank Status \\
\hline ABG & 2.284 & Quoted \\
ADB & 1.886 & Quoted \\
BAB & 0.856 & Unquoted \\
BOA & 0.853 & Unquoted \\
CALL & 0.752 & Quoted \\
EGH & 0.609 & Quoted \\
FAB & 0.642 & Unquoted \\
FBL & 1.143 & Unquoted \\
FNB & 1.217 & Unquoted \\
GCB & 0.595 & Quoted \\
GTB & 1.402 & Unquoted \\
RBG & 0.774 & Quoted \\
SBG & 1.087 & Unquoted \\
SCB & 1.052 & Unquoted \\
SOGEGH & 0.740 & Quoted \\
TBL & 0.238 & Quoted \\
UBA & 1.332 & Unquoted \\
UMB & 1.207 & Unquoted
\end{tabular}

\section{TOTAL BANKS}

18

$95 \%$

Source: Financial Reports (2015-2018).

Table 16: Assessments of Banks classified into Grey zone using Altman z-Scores (Model 1) on a yearly basis.

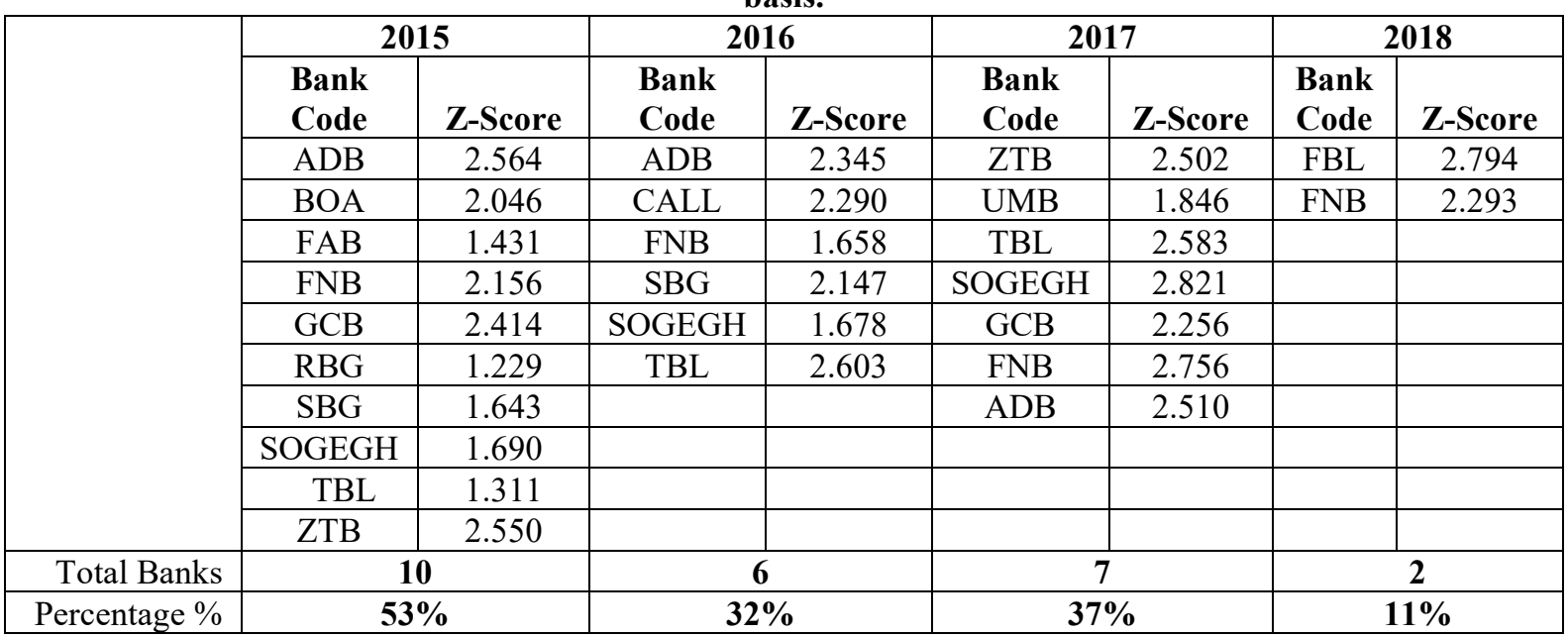

Source: Financial Reports (2015 - 2018)

Table17: Assessments of Banks classified into Grey zone using average Altman z-Scores (Model 1)

\begin{tabular}{ccc} 
Bank Code & Average $\boldsymbol{Z}$-Score & Bank Status \\
\hline FNB & 2.000 & Unquoted \\
GCB & 2.749 & Quoted \\
SOGEGH & 2.305 & Quoted \\
TBL & 2.361 & Quoted \\
ZTB & 2.253 & Unquoted
\end{tabular}

Total Banks

Percentage \%
5

$26 \%$

Source: Financial Reports (2015-2018). 


\subsection{Presentation and Assessments of M-Scores}

Scrutinizing the annual financials using the Beneish model provides reasons for appreciating and assessing whether the annual financials used in evaluating hypothesis 1 was manipulated. To achieved these, the Beneish M-Score model was employed to establish whether the annual statements were manipulated and the output is presented in table 18, $19 \& 20$.

Table 18: Results of M-Score using Beneish (1999) Model. (N=19)

\begin{tabular}{cccccc}
\hline Bank Code & $\begin{array}{c}\mathbf{2 0 1 5} \\
\text { M-Score }\end{array}$ & $\begin{array}{c}\mathbf{2 0 1 6} \\
\text { M-Score }\end{array}$ & $\begin{array}{c}\mathbf{2 0 1 7} \\
\text { M-Score }\end{array}$ & $\begin{array}{c}\mathbf{2 0 1 8} \\
\text { M-Score }\end{array}$ & $\begin{array}{c}\text { Average } \\
\text { M-Score }\end{array}$ \\
\hline ABG & 5.854 & $(0.141)$ & 0.132 & 0.176 & 1.505 \\
ADB & $(1.482)$ & $(2.110)$ & $(1.771)$ & 1.307 & $(1.014)$ \\
BAB & $(1.699)$ & $(1.452)$ & $(1.387)$ & $(1.581)$ & $(1.530)$ \\
BOA & 4.317 & $(1.882)$ & $(1.103)$ & $(0.968)$ & 0.091 \\
CALL & $(1.501)$ & $(1.935)$ & $(1.599)$ & $(1.500)$ & $(1.634)$ \\
EGH & $(2.129)$ & 0.174 & $(2.760)$ & $(1.804)$ & $(1.630)$ \\
FAB & $(2.532)$ & 0.733 & $(1.811)$ & $(0.507)$ & $(0.979)$ \\
FBL & 4.337 & $(1.788)$ & $(1.752)$ & 2.454 & $(3.473$ \\
FNB & $(20.694)$ & 0.546 & 3.774 & $(1.449)$ & $(1.291)$ \\
GCB & $(1.331)$ & $(1.026)$ & $(1.358)$ & $(1.396)$ & $(1.062)$ \\
GTB & $(1.468)$ & $(1.103)$ & $(1.282)$ & $(1.436)$ & $(1.282)$ \\
RBG & $(1.671)$ & $(0.336)$ & $(2.002)$ & $(1.438)$ & $(0.604)$ \\
SBG & 0.258 & 0.201 & $(12.162)$ & $(1.041)$ & $(0.291)$ \\
SCB & 24.645 & $(8.138)$ & $(3.188)$ & 7.172 & $(0.861)$ \\
SOGEGH & 0.323 & $(1.539)$ & 10.719 & $(1.859)$ & $(4.55)$ \\
TBL & $(15.971)$ & $(2.039)$ & $(1.589)$ & $(4.782)$ & $(2.599)$ \\
UBA & $(37.436)$ & 1.315 & $(4.013)$ & $(3.525)$ \\
UMB & $(0.177)$ & $(6.770)$ & &
\end{tabular}

Source: Financial Reports (2015-2018).

Table 19: Assessments of Banks M-Score values under manipulation and non-manipulation based on yearly score. (Model 3, 2015-2018).

\begin{tabular}{|c|c|c|c|c|c|c|c|c|}
\hline \multirow[t]{3}{*}{ Code } & \multicolumn{2}{|r|}{2015} & \multicolumn{2}{|r|}{2016} & \multicolumn{2}{|r|}{2017} & \multicolumn{2}{|r|}{2018} \\
\hline & M- & Zone Of & M- & Zone Of & M- & Zone Of & M- & Zone Of \\
\hline & Score & Discrimination & Score & Discrimination & Score & Discrimination & Score & Discrimination \\
\hline$A B G$ & 5.854 & Manipulation & $(0.14)$ & Manipulation & 0.132 & Manipulation & 0.176 & Manipulation \\
\hline$A D B$ & (1.482) & Manipulation & (2.11) & Manipulation & (1.771) & Manipulation & 1.307 & Manipulation \\
\hline$B A B$ & (1.699) & Manipulation & (1.45) & Manipulation & (1.387) & Manipulation & (1.58) & Manipulation \\
\hline$B O A$ & 4.317 & Manipulation & (1.88) & Manipulation & (1.103) & Manipulation & $(0.96)$ & Manipulation \\
\hline$C A L L$ & (1.501) & Manipulation & (1.93) & Manipulation & (1.599) & Manipulation & (1.50) & Manipulation \\
\hline$E G H$ & (2.129) & $\begin{array}{l}\text { Manipulation } \\
\text { Non-manipulation }\end{array}$ & 0.174 & Manipulation & (2.760) & $\begin{array}{c}\text { Non- } \\
\text { manipulation }\end{array}$ & (1.80) & Manipulation \\
\hline$F A B$ & $(2.532)$ & & 0.733 & Manipulation & (1.811) & Manipulation & $(0.30)$ & Manipulation \\
\hline$F B L$ & 4.337 & Manipulation & (1.78) & Manipulation & $(1.752)$ & Manipulation & (0.50) & Manipulation \\
\hline & & Non-manipulation & & & & No- & & No- \\
\hline$F N B$ & (20.694) & & 0.546 & Manipulation & 3.774 & manipulation & 2.454 & manipulation \\
\hline$G C B$ & (1.331) & Manipulation & (1.02) & Manipulation & (1.358) & Manipulation & (1.44) & Manipulation \\
\hline$G T B$ & (1.468) & Manipulation & (1.10) & Manipulation & (1.282) & Manipulation & (0.39) & Manipulation \\
\hline$R B G$ & (1.671) & Manipulation & $(0.33)$ & Manipulation & (2.002) & Manipulation & (1.12) & Manipulation \\
\hline$S B G$ & 0.258 & Manipulation & 0.201 & Manipulation & (1.438) & Manipulation & (1.43) & Manipulation \\
\hline $\begin{array}{c}S C B \\
S O G F G\end{array}$ & 24.645 & Manipulation & (8.13) & $\begin{array}{c}\text { Non- } \\
\text { Manipulation }\end{array}$ & (12.16) & $\begin{array}{c}\text { Non- } \\
\text { manipulation }\end{array}$ & (5.50) & $\begin{array}{c}\text { Non- } \\
\text { manipulation }\end{array}$ \\
\hline & 0.323 & Manipulation & (1.53) & Manipulation & (1.188) & Manipulation & (1.04) & Manipulation \\
\hline$T B L$ & (15.97) & Non-manipulation & (2.03) & Manipulation & (3.267) & $\begin{array}{c}\text { Non- } \\
\text { manipulation }\end{array}$ & 0.494 & Manipulation \\
\hline$U B A$ & (37.43) & Non-manipulation & 1.315 & $\begin{array}{l}\text { Manipulation } \\
\text { Non- }\end{array}$ & 10.719 & Manipulation & 7.172 & Manipulation \\
\hline$U M B$ & (0.177) & Manipulation & (6.77) & Manipulation & (1.589) & Manipulation & (1.85) & Manipulation \\
\hline$Z T B$ & (2.191) & Manipulation & (3.11) & $\begin{array}{c}\text { Non- } \\
\text { manipulation }\end{array}$ & (4.013) & $\begin{array}{c}\text { Non- } \\
\text { manipulation }\end{array}$ & (4.78) & $\begin{array}{c}\text { Non- } \\
\text { manipulation }\end{array}$ \\
\hline
\end{tabular}

Source: Financial Reports (2015 - 2018). 
Table 20: Assessments of Banks M-Score values based on Average M-scores (Model 3), 2015-2018

\begin{tabular}{cccc}
\hline Bank Code & Average M-Score & Zone Of Discrimination & Banks Status \\
\hline$A B G$ & 1.505 & Manipulation & Quoted \\
$A D B$ & $(1.014)$ & Manipulation & Quoted \\
$B A B$ & $(1.530)$ & Manipulation & Unquoted \\
$B O A$ & 0.091 & Manipulation & Unquoted \\
$C A L L$ & $(1.634)$ & Manipulation & Quoted \\
$E G H$ & $(1.630)$ & Manipulation & Quoted \\
$F A B$ & $(0.979)$ & Manipulation & Unquoted \\
$F B L$ & 0.073 & Manipulation & Unquoted \\
$F N B$ & $(3.480)$ & Non- Manipulation & Unquoted \\
$G C B$ & $(1.291)$ & Manipulation & Quoted \\
$G T B$ & $(1.062)$ & Manipulation & Unquoted \\
$R B G$ & $(1.282)$ & Manipulation & Quoted \\
$S B G$ & $(0.604)$ & Manipulation & Unquoted \\
$S C B$ & $(0.291)$ & Manipulation & Quoted \\
$S O G E G H$ & $(0.861)$ & Manipulation & Quoted \\
$T B L$ & $(5.196)$ & Non- Manipulation & Quoted \\
$U B A$ & $(4.557)$ & Non- Manipulation & Unquoted \\
$U M B$ & $(2.599)$ & Manipulation & Unquoted \\
$Z T B$ & $(3.525)$ & Non- Manipulation & Unquoted \\
\hline
\end{tabular}

Source: Financial Reports $(2015-2018)$.

\subsection{Discussion of Results}

Tables 8 and 9 show the results of Z-Scores computed from the secondary data collected from 2015 to 2018 . Altman Z-Score computation reported that on average $74 \%$ of the banks showed an impressive Z-Score performance of being financially sound (see table 14). In the case of a year-on-year score, the result showed a progressive Z-Score performance ranging from $63 \%$ to $89 \%$ of the banks classified as safe from distressed for the period of three years except 2015 which recorded $42 \%$ (see also table 10). Also, the result classified $53 \%, 32 \%$, $37 \%$, and $11 \%$ not financially distressed but in the zone of distress or Grey Zone in the year 2015 through 2018 respectively (see also table 16). Note, it is important to report that the model misclassified (Type II error) one bank in the year 2015 representing $5 \%$ (see table 11). In general, the model correctly classified $74 \%$ of the banks as safe and classified $26 \%$ of the banks into the grey zone on average. This result is consistent with the result of Soon et.al (2014), Ezejiofor (2014), and Jyothi and Veni (2018).

Taffler Z-Score computation, on the other hand, revealed that on average $95 \%$ of the banks showed remarkable Z-Score performance of being safe from bankruptcy (see table 15). Using a year-on-year score to determine distress revealed an impressive Z-Score performance of $95 \%$ of the banks classified as safe from distressed through 2016 to 2018 except 2015 which recorded $100 \%$ of the banks as healthy (see table 12). However, the model misclassified one non-failed bank as failed for the period 2016 to 2018 representing (5\%) error rate (see table 13). The result of the two models indicates that the commercial banks selected for the study are less financially distressed hence $\mathbf{H}_{2}$ hypothesis is supported.

Tables 18, 19, and 20 reports the result and assessments of m-score calculated from the financial data of 19 commercial banks spinning from 2015 to 2018. A carefully look at Tables 18 and 19 revealed that financial statements of eleven banks (58\%) showed signs of possible manipulations as far back 2015 to 2018 as their MScore figure is above the benchmark score for non- manipulated earning figures of negative 2.22 . The remaining eight banks showed signs of manipulation for only three-years score representing $(42 \%)$. None of the banks were found to be free from financial statement fraud in all the four-years study period. The four-year average M-Score in table 20 revealed 79 percent of the banks engaging in earnings manipulation as their average M-Score lies above the benchmark figure of negative 2.22 .

Therefore, a detailed overview of the results in table 18 as confirmed by Tables 19 and 20 revealed that earnings of all the banks under review were manipulated. This implies that the four-year financial statements were manipulated to hide the true financial position of the banks hence the predictive accuracy rate of Altman and Taffler model may not reflect the true picture of the models, therefore $\mathbf{H}_{3}$ hypothesis is supported. This result is similar to that of McCarthy, J. [2017] which reported that the financial statements for the five years studied were manipulated by the management of Enron corporation to hide the true picture of the company's distress status. Contrary to these findings is Amoa-Gyarteng, K. [2014] which analyzed a listed firm in Ghana for early warning signs of bankruptcy and financial statement fraud with the Beneish model. His findings revealed that the companies were not engaging in financial statement fraud and the differences in the result can be attributed to sector disparities. 


\subsection{Assessments of Classification Accuracy of Altman and Taffler Z-Score Model.}

The classification accuracy of Altman [2000] and Taffler's [1983] Z-Score models was evaluated using a sample of 19 commercial banks. The z-scores are obtained for both models using four years' annual financial data. The accuracy is calculated by dividing the number of banks correctly classified by the total number of banks in the sample. The tenacity of Altman's [1968] study was to develop a model that could predict a corporate fate in the light of failed, non-failed and zone of ignorance. However, the question of the accuracy determination method was not dealt with due to his inability to validate his model. Therefore, in other to validate the model in different countries and circumstances, we deem the accuracy calculation important. To meritoriously evaluate the predictive ability between the two models, it is statistically appropriate to exclude the uncertainty Zone count area thus zone which cannot be regarded as failed or non-failed.

Table 21 presents the results of the calculation of both Taffler [1983] and Altman [2000] model. The Altman model displays impressive predictive accuracy. The general drift for all the 19 commercial banks, from 2015 to 2018 showed an average classification accuracy of $66 \%$ using the yearly classification assessment. In the case of using the overall average Z- scores of each bank in the study sample, the model does improve its classification power to $74 \%$ (see table 14). However, the model tends to misclassify one bank (type II error) in the year 2015 representing 5\%. In the case of Taffler [1983], the model does extremely well for predicting the banks with accuracy ranging from $95 \%$ to $100 \%$ between the year range from 2015 to 2018 with the overall predictive power of $95 \%$. Similarly, the model misclassifies one non-failed bank into failed in all the years except 2015 . Hence the model displayed a predictive error rate of 5\% (see table 13). In general, it can be concluded that the predictive accuracy of the Taffler 1983 model is higher than that of Altman's [2000] model in the banking industry in Ghana with a statistical difference of $21 \%$.

Table 21: Assessment of Classification Accuracy of Model 1\&2 excluding Grey-zone.

\begin{tabular}{ccccc}
\hline YEAR & ALTMAN (2000) & MODEL & \multicolumn{1}{c}{ TAFFLER (1983) MODEL } \\
\hline & NO. of banks & $\%$ & NO. of Banks & $\%$ \\
$\mathbf{2 0 1 5}$ & 8 & $42 \%$ & 19 & $100 \%$ \\
$\mathbf{2 0 1 6}$ & 13 & $68 \%$ & 18 & $95 \%$ \\
$\mathbf{2 0 1 7}$ & 12 & $63 \%$ & 18 & $95 \%$ \\
$\mathbf{2 0 1 8}$ & 17 & $89 \%$ & 18 & $95 \%$ \\
AVERAGE & & $\mathbf{6 6 \%}$ & & $\mathbf{9 6 \%}$ \\
USING AVERAGE Z-SCORES & 14 & & $\mathbf{1 8}$ & $\mathbf{9 5 \%}$ \\
\hline
\end{tabular}

Source: Financial Reports (2015 - 2018).

\subsection{Assessment of Hypothesis.}

Taking into account the result reported in tables 8 and 9 as confirmed by tables 10 and 12, and the results shown in tables 14 and 15, indicate that seventy-four (74\%) and ninety- five (95\%) of the commercial banks showed an impressive Z-Score performance under Altman and Taffler models respectively and may not be said to be in any state of financial distress. Therefore, hypothesis $\mathbf{H}_{\mathbf{1}}$ which states that the commercial banks are more financially troubled using both Altman and Taffler model following the four years under review is rejected and the alternative hypothesis $\mathbf{H}_{2}$ which states the understudy banks are less financially troubled using the Altman and Taffler model is accepted.

The results in tables 18 and 19 as confirmed by table 20, it can be concluded that on average, seventy-nine (79\%) of the commercial banks reported being manipulating their financial statement over the study period of four years. Hence, the $\mathbf{H}_{3}$ which states that the annual financials published by the commercial banks is likely to exhibit signs of manipulations to meet better performance is accepted and the alternative $\mathbf{H}_{4}$ which states that the annual financial statements published by the commercial banks were not manipulated is rejected. A summary of the assessment is presented in table 22.

Table 22: summary of hypothesis assessment

\begin{tabular}{|l|l|}
\hline HYPOTHESIS & REMARKS \\
\hline $\mathbf{H}_{1} \quad$ (Banks are Financially distressed) & Rejected \\
\hline $\mathbf{H}_{2}$ (Banks are not Financially distressed) & Accepted $^{* *}$ \\
\hline $\mathbf{H}_{3}$ (Banks manipulate their financials) & Accepted $^{* *}$ \\
\hline $\mathbf{H}_{4}$ (Banks do not manipulate their financials) & Rejected $^{2}$ \\
\hline
\end{tabular}

\subsection{Conclusion and Recommendations}

Financial distress is a term used in finance theory to indicate that a company is incapable to meet debt covenants or that cash flow forecasts show that a company will shortly run out of operations [Brigham \& Daves, 2004]. The purpose of this study was to assess the bankruptcy and financial fraud of both listed and unlisted commercial banks in Ghana. The study employed three models namely, Altman [2000] and Taffler [1983] thus model 1\&2 which is 
used often for assessing financial distress of non-manufacturers and companies in an emerging economy and the Beneish [1999] model which was devised to evaluate possibilities of financial statement fraud to evaluate the financial statement of 19 sampled commercial banks in Ghana.

The outcome obtained from the computation of Altman and Taffler's Z-Score revealed that on average 14 $(74 \%)$ and $18(95 \%)$ of the 19 banks were in the safe zone with an average Z-Score ranges from 2.948 to 6.739 (Model 1) and 0.238 to 2.284 (Model 2) for four-years study period. Altman model further reported 5 (26\%) of the banks into the Zone of ignorance or grey zone with an average Z-Score range from 2.00 to 2.749 for the fouryears study period. However, both models misclassified one (5\%) non-failed bank as failed based on year-on-year assessments representing a $5 \%$ error rate.

The results of M-Score (Model 3) calculation revealed that the financial statements of eleven (11) representing $58 \%$ of the banks showed signs of manipulations for the years under review whilst eight (8) representing $42 \%$ of the banks showed signs of financial statement manipulations for a period of three years. Therefore, none of the banks were found to be free from financial statement manipulations for all the study period. Hence the study concludes that financial statements published by the 19 sampled banks were manipulated to hide the true picture of their performance.

Based on the results obtained, it is evident that commercial banks in Ghana are less financially distressed thus having the highest Z- Score performance. This might be the result of the bank of Ghana's (BOG) comprehensive reform agenda to strengthen the regulatory and supervisory framework for a more resilient and robust banking sector in Ghana. As part of the measures taken by BOG to cleanse the banking sector, a new minimum capital requirement was set for all universal banks to meet as of 2018. This has resulted in some banks had their licenses withdrawn, others have been merged for their inability to raise the new minimum capital requirement. This reform could force banks that are financially distressed to manage or manipulates their earnings to hide the real picture of the bank's operations in order to mislead the public as evident in the M-Score analysis. McCarthy [2017], argued that a manipulated financial statement could not be detected by predictive models to accurately forecast the bankruptcy of companies without the Beneish M-Score Model due to the fact that earnings were manipulated in Enron's financial statement prior to its collapse though Altman model predicted Enron corporation as safe from insolvency. Therefore, there is a high possibility that the banks that are faced with financial distress would manipulate their earnings by adjusting amortization, delay in recognizing expenses, recording sales early or capitalized on other accounting limitations or tricks that favor the bank to show better performance.

Mulford and Comiskey [1996] defined earnings management as the vigorous manipulation of accounting bookkeeping for the purpose of creating an altered impression of business performance. The study, therefore, recommends that the Beneish model, if applied well together with the failure predictions model by researchers, can provide reliable findings for policymaking. The study further recommends that auditors, investors, management, and shareholders, when making good use of the Beneish Model, can provide potential 'red flags' for further investigations to be carried out. This exposes could prompt better audit work in order to show a true and fair financial position of the business.

\section{References:}

Adeyemi, B. [2011]. Bank failure in Nigeria: A consequence of capital inadequacy, lack of transparency and nonperforming loans. Banks and Bank systems, 6(1), 99-109.

Al-Gharaibeh, M., Zurigat, Z., \& Al-Harahsheh, K. [2013]. The effect of ownership structure on policy in Jordanian companies. Interdisciplinary journal of contemporary research in business, 4(9), 769-796.

Al-Khatib, H. B., \& Al-Horani, A. [2012]. Predicting financial distress of public companies listed on the Amman Stock Exchange. European Scientific Journal, 8(15).

Altman, E. I. (1968). Financial ratios, discriminant analysis and the prediction of corporate bankruptcy. The journal of finance, 23(4), 589-609.

Altman, E.I. (2000), "Predicting financial distress of companies: Revisiting the Z-score and ZETA models", Stern School of Business, New York University, 9-12.

Amoa-Gyarteng, K. (2014). Analyzing a listed firm in Ghana for early warning signs of bankruptcy and financial statement fraud: An empirical investigation of AngloGold Ashanti. European Journal of Business and Management, 6(5), 10-17.

Appiah, K.O. (2011), "Corporate Failure Prediction: Some Empirical Evidence from Listed Firms in Ghana", China-USA Business Review, 10(1).

Baharin, I., \& Sentosa, I. (2013). Capital Structure and the Post Performance Factors of Malaysian PN 17 Firms. International Journal of Business and Management Invention, 2(3), 50-56.

Beneish, M. D. (1999). The detection of earnings manipulation. Financial Analysts Journal, 55(5), 24-36.

Beneish, M. D., Lee, C., \& Nichols, D. C. (2012). Fraud detection and expected returns. Available at SSRN 1998387.

Bhunia, A., Khan, S. I. U., \& Mukhuti, S. (2011). Prediction of Financial Distress - A Case Study of Indian 
Companies. Asian Journal of Business Management, 3(3), 210-218.

Clovis, M. S., \& Katuka, T. M. Assessing The Financial Soundness of Trust Merchant Bank/Drc: An Application of Altman's Bankruptcy Prediction Model.

Ezejiofor, R. A., Nzewi, U. C., \& Okoye, P. V. (2014). Corporate bankruptcy: An application of the Altman model in predicting the potential of failure in the Nigerian banking sector. International Journal of Empirical Finance, 2(4), 152-171.

Glautier, M. W. E. \& Underdown, B. (2001). Accounting theory and practice (7th ed.). Edinburgh: Pearson Education Ltd.

Grice, J. S., \& Ingram, R. W. (2001). Tests of the generalizability of Altman's bankruptcy prediction model. Journal of Business Research, 54(1), 53-61.

Harrington, C. (2005). Formulas for detection. Analysis ratios for detecting financial statement fraud. Fraud Magazine, Association of Certified Fraud Examiners.

Kumar, D., Kumar, A., \& Choudhary, P. K. (2018). Emerging Issues and Dimensions of Indian Society. Education Publishing.

Kumari, I. G. S. (2017). A Study on the Financial Performance of Foreign Commercial Banks in Sri Lanka: An Application of Camel Rating System. Economics, Commerce and Trade Management: An International Journal (ECTIJ), 1(1), 59-70.

Lev, B., \& Thiagarajan, R. S. (1993). Fundamental Information Analysis. Journal of Accounting Research, 31(2), 190-215.

Lev, B., \& Thiagarajan, S. R. (1993). Fundamental information analysis. Journal of Accounting Research, 31(2), $190-215$.

MacCarthy, J. (2017). Using Altman Z-score and Beneish M-score models to detect financial fraud and corporate failure: A case study of Enron Corporation. International Journal of Finance and Accounting, 6(6), 159-166.

Mulford, C., \& Comiskey, E. (1996). Financial Warnings: Detecting Earning Surprises. Avoiding Business Troubles, Implementing Corrective Strategies, 1.

Mwawughanga, C. W., \& Ochiri, G. (2017). Application of Edward Altman's Z Score model on measuring the financial health of commercial banks in Kenya. The Strategic Journal of Business \& Change Management, 4(2), 722-741.

Panneerselvam, R. (2008). Research methodology, New Delhi: Prentice-Hall of India Private Limited.

Pustylnick, I. (2009). Combined Algorithm of Detection of Manipulation in Financial Statements. Retrieved on January 4, 2015, from http://www.ssrn.com/abstract=1422693.

Ray, S. (2011). Assessing Corporate Financial Distress in the Automobile Industry of India: An Application of Altman's Model. Research Journal of Finance and Accounting, 2(3), 155-169.

Safeena, R., Kammani, A., \& Date, H. (2017). An exploratory study of Internet banking technology adoption. International Journal of E-Services and Mobile Applications (IJESMA), 9(2), 23-43.

Samanhyia, S., Oware, K. M., \& Anisom-Yaansah, F. (2016). Financial distress and bankruptcy prediction: Evidence from Ghana. Expert Journal of Finance, 4(1), 52-65.

Sami, B. J. (2013). Financial Distress and Bankruptcy costs. In H. Dincer \& U. Hacioglu. Global Strategies for Banking and Finance (369-379). United States: IGI Global.

Sarker, S., Ghosh, S. K., \& Palit, M. (2015). Role of banking-sector to inclusive growth through inclusive finance in Bangladesh. Studies in business and economics, 10(2), 145-159.

Soon, Ng Kim, Mohammed, A. Abusalah, and Mostafa, M. Rahil (2014) Using Altman's Z-Score Model to Predict the Financial Hardship of Companies Listed in the Trading Services Sector of Malaysian Stock Exchange. Aust. J. Basic \& Appl. Sci., 8(6): 379-384.

Sulphey, M. M., \& Nisa, S. (2013). The analytical implication of Altman's Z-score analysis of BSE listed smallcap companies. Journal of Commerce and Management Perspective, 2(4), 45-155.

Taffler, R. J. (1983). The assessment of company solvency and performance using a statistical model. Accounting and Business Research, 13(52), 295-308.

USDin, S. D., \& Bloom, N. M. (2012). Identifying Signs, a Company Is in Financial Distress. The Legal Intelligencer, 245,80 .

Vuran, B. (2009). Prediction of business failure: A comparison of discriminant and logistic regression analyses. İstanbul Üniversitesi İşletme Fakültesi Dergisi, 38(1), 47-63.

Warshavsky, M. (2012). Analyzing Earnings Quality as a Financial Forensic Tool. Financial Valuation and Litigation Expert Journal, (39), 16-20.

Wilkinson, B. (2009). Predicting the risk of corporate failure for Australian companies: A fresh approach using probability-based tri-dimensional modeling, Unpublished doctoral thesis, University of Wollongong, Australia.

Zeytınoglu, E. \& Akarim, Y. D. (2013). Financial Failure Prediction Using Financial Ratios: An Empirical Application on the Istanbul Stock Exchange. Journal of Applied Finance \& Banking, 3(3), 107-116. 
Zhuang, Q., \& Chen, L. (2014). Dynamic prediction of financial distress based on Kalman filtering. Discrete Dynamics in Nature and Society, 2014.

INTERNET SOURCE:

1. http://annualreportsghana.com/Services/Reports.aspx

2. https://www.african-markets.com/en/stock-markets/gse/listed-companies

3. Companies website

APPENDIXES:

(A)

\begin{tabular}{|l|l|l|}
\hline \multicolumn{4}{|c|}{ DESCRIPTION OF BANKS SELECTED FOR THE STUDY } \\
\hline BANK NAME & BANK CODE & STATUS \\
\hline TRUST BANK (THE GAMBIA) & TBL & LISTED ON GSE \\
\hline STANDARD CHARTERED BANK GHANA & SCB & LISTED ON GSE \\
\hline SOCIETE GENERALE GHANA & SOGEGH & LISTED ON GSE \\
\hline REPUBLIC BANK & RBGH & LISTED ON GSE \\
\hline GHANA COMMERCIAL BANK & GCB & LISTED ON GSE \\
\hline ECOBANK GHANA & EGH & LISTED ON GSE \\
\hline CALL BANK & CAL & LISTED ON GSE \\
\hline AGRICULTURAL DEVELOPMENT BANK & ADB & LISTED ON GSE \\
\hline ACCESS BANK GHANA & ABG & LISTED ON GSE \\
\hline ZINITH BANK & ZTB & UNLISTED ON GSE \\
\hline STANBIC BANK GHANA & SBG & UNLISTED ON GSE \\
\hline UNIVERSAL MERCHANT BANK & UMB & UNLISTED ON GSE \\
\hline UNIVERSAL BANK OF AFRICA & UBA & UNLISTED ON GSE \\
\hline GUARANTEE TRUST BANK & GTB & UNLISTED ON GSE \\
\hline FIRST NATIONAL BANK & FNB & UNLISTED ON GSE \\
\hline FIDELITY BANK & FBL & UNLISTED ON GSE \\
\hline BANK OF AFRICA & BOA & UNLISTED ON GSE \\
\hline BARCLAYS BANK & BAB & UNLISTED ON GSE \\
\hline FIRST ATLANTIC BANK & FAB & UNLISTED ON GSE \\
\hline
\end{tabular}

(B)

\begin{tabular}{|c|c|c|c|c|c|c|}
\hline \multirow[b]{2}{*}{ BANK CODE } & \multicolumn{5}{|c|}{ DATA PRESENTATION OF ALTMAN Z-SCORE VARIABLES } & \multirow[b]{2}{*}{$\begin{array}{l}\text { SALES/TA } \\
\text { (X5) }\end{array}$} \\
\hline & YEARS & WC/TA (X1) & RE/TA (X2) & $\begin{array}{l}\mathrm{PBT} / \mathrm{TA} \\
(\mathrm{X} 3)\end{array}$ & $\begin{array}{l}\text { EQTY/TL } \\
\text { (X4) }\end{array}$ & \\
\hline \multirow[t]{4}{*}{ FAB } & 2015 & $(0.12143)$ & $(0.00429)$ & 0.11142 & 0.14476 & 1.11760 \\
\hline & 2016 & 0.07256 & 0.00011 & 0.11414 & 0.16786 & 4.47974 \\
\hline & 2017 & 0.06164 & 0.01787 & 0.08336 & 0.15637 & 6.41731 \\
\hline & 2018 & 0.12206 & $(0.00043)$ & 0.09331 & 0.22793 & 2.55834 \\
\hline \multirow[t]{4}{*}{$\mathrm{BAB}$} & 2015 & 0.14423 & 0.05509 & 0.07136 & 0.19271 & 8.13866 \\
\hline & 2016 & 0.14208 & 0.06209 & 0.08002 & 0.15944 & 5.01025 \\
\hline & 2017 & 0.17362 & 0.08521 & 0.09242 & 0.21473 & 4.84931 \\
\hline & 2018 & 0.14531 & 0.05460 & 0.00617 & 0.17467 & 3.28248 \\
\hline \multirow[t]{4}{*}{$\mathrm{BOA}$} & 2015 & 0.33728 & $(0.02594)$ & 0.03447 & 1.37424 & 1.14448 \\
\hline & 2016 & 0.09908 & $(0.02527)$ & 0.02195 & 0.16719 & 4.47684 \\
\hline & 2017 & 0.25751 & $(0.01662)$ & 0.02487 & 0.16324 & 4.63892 \\
\hline & 2018 & 0.28372 & $(0.01258)$ & 0.02970 & 0.19820 & 3.53988 \\
\hline \multirow[t]{4}{*}{ CAL } & 2015 & 0.15768 & 0.06163 & $(0.05230)$ & 0.17780 & 2.94975 \\
\hline & 2016 & 0.10755 & 0.04027 & 0.00336 & 0.16236 & 2.10439 \\
\hline & 2017 & 0.11797 & 0.06549 & 0.04946 & 0.18160 & 2.95850 \\
\hline & 2018 & 0.14339 & 0.01076 & 0.04261 & 0.16473 & 2.99767 \\
\hline \multirow[t]{4}{*}{ EGH } & 2015 & 0.03986 & 0.00842 & 0.00258 & 0.11045 & 5.53973 \\
\hline & 2016 & 0.09874 & 0.00398 & $(0.00394)$ & 0.12335 & 5.85622 \\
\hline & 2017 & 0.08333 & 0.02409 & 0.04336 & 0.13907 & 8.55420 \\
\hline & 2018 & 0.09434 & 0.02142 & 0.03506 & 0.13855 & 7.95589 \\
\hline ABG & 2015 & 0.57782 & 0.67737 & 0.11316 & 0.33904 & 1.87079 \\
\hline
\end{tabular}




\begin{tabular}{|c|c|c|c|c|c|c|}
\hline & 2016 & 0.56512 & 0.68210 & 0.14909 & 0.26674 & 2.37632 \\
\hline & 2017 & 0.49315 & 0.10253 & 0.00920 & 0.19998 & 3.91392 \\
\hline & 2018 & 0.43687 & 0.10758 & 0.03641 & 0.52302 & 4.90046 \\
\hline \multirow[t]{4}{*}{ GCB } & 2015 & 0.21676 & 0.02373 & 0.06363 & 0.28762 & 2.07451 \\
\hline & 2016 & 0.17560 & 0.02988 & 0.13160 & 0.24874 & 1.68480 \\
\hline & 2017 & 0.20224 & 0.04811 & 0.16137 & 0.29380 & 1.70385 \\
\hline & 2018 & 0.13661 & 0.00195 & 1.74990 & 0.05205 & 1.18750 \\
\hline \multirow[t]{4}{*}{ FBL } & 2015 & 0.18022 & 0.01161 & 0.05003 & 0.13960 & 3.77228 \\
\hline & 2016 & 0.17523 & 0.00496 & 0.00445 & 0.13405 & 3.50107 \\
\hline & 2017 & 0.20023 & 0.00732 & 0.02517 & 0.11029 & 2.83183 \\
\hline & 2018 & 0.32449 & 0.00467 & 0.03451 & 0.10936 & 2.40948 \\
\hline \multirow[t]{4}{*}{$\mathrm{ADB}$} & 2015 & 0.17809 & 0.10925 & 0.07566 & 0.21417 & 1.87335 \\
\hline & 2016 & 0.21585 & 0.11578 & 0.07385 & 0.20163 & 2.65516 \\
\hline & 2017 & 0.19150 & 0.08258 & 0.03232 & 0.13181 & 1.89697 \\
\hline & 2018 & 0.11640 & 0.04707 & 0.04197 & 0.14237 & 2.78378 \\
\hline \multirow[t]{4}{*}{ FNB } & 2015 & 0.80344 & $(0.03066)$ & $(0.03170)$ & 0.52823 & 1.48567 \\
\hline & 2016 & 0.40538 & $(0.04467)$ & $(0.02869)$ & 0.91767 & 1.11141 \\
\hline & 2017 & 0.45296 & $(0.15211)$ & $(0.10532)$ & 1.11089 & 2.42491 \\
\hline & 2018 & 0.69081 & $(0.12340)$ & $(0.05759)$ & 2.04142 & 1.22672 \\
\hline \multirow[t]{4}{*}{ GTB } & 2015 & 0.27248 & 0.02022 & 0.04963 & 0.21667 & 4.96005 \\
\hline & 2016 & 0.26027 & 0.03214 & 0.05893 & 0.22323 & 3.59215 \\
\hline & 2017 & 0.26397 & 0.03880 & 0.06998 & 0.25756 & 2.98051 \\
\hline & 2018 & 0.19593 & 0.02937 & 0.07948 & 0.23258 & 8.97192 \\
\hline \multirow[t]{4}{*}{ RBGH } & 2015 & 0.11611 & $(0.00860)$ & $(0.02367)$ & 0.12963 & 1.17338 \\
\hline & 2016 & 0.03807 & $(0.02569)$ & $(0.03071)$ & 0.08230 & 3.92534 \\
\hline & 2017 & 0.08196 & $(0.01563)$ & 0.02725 & 0.12208 & 4.70089 \\
\hline & 2018 & 0.20715 & $(0.02278)$ & 0.01584 & 0.21087 & 4.41160 \\
\hline \multirow[t]{4}{*}{ SOGEGH } & 2015 & 0.20687 & 0.02535 & 0.03232 & 0.15274 & 1.35859 \\
\hline & 2016 & 0.18073 & 0.03210 & 0.03752 & 0.15714 & 1.34125 \\
\hline & 2017 & 0.12189 & 0.05118 & 0.04553 & 0.22848 & 2.45763 \\
\hline & 2018 & 0.22062 & 0.00882 & 0.03066 & 0.02571 & 2.91968 \\
\hline \multirow[t]{4}{*}{ SCB } & 2015 & 0.17935 & 0.03133 & 0.02703 & 0.19724 & 6.85914 \\
\hline & 2016 & 0.18693 & 0.05319 & 0.07901 & 0.21207 & 5.04808 \\
\hline & 2017 & 0.20474 & 0.07575 & 0.08840 & 0.23877 & 3.70047 \\
\hline & 2018 & 0.20999 & 0.03862 & 0.05466 & 0.21325 & 3.57160 \\
\hline \multirow[t]{4}{*}{ TBL } & 2015 & $(0.02923)$ & 0.02015 & 0.03544 & 0.16713 & 1.13696 \\
\hline & 2016 & $(0.03198)$ & 0.01842 & 0.02222 & 0.15767 & 2.48000 \\
\hline & 2017 & $(0.02515)$ & 0.01333 & 0.01962 & 0.12915 & 2.47955 \\
\hline & 2018 & $(0.01713)$ & 0.00997 & 0.01875 & 0.11652 & 3.78967 \\
\hline \multirow[t]{4}{*}{ UBA } & 2015 & $(0.33630)$ & 0.01690 & 0.03736 & 0.12328 & 3.85903 \\
\hline & 2016 & 0.67968 & 0.00927 & 0.05630 & 0.09653 & 2.21839 \\
\hline & 2017 & 0.23958 & 0.03332 & 0.01801 & 0.15838 & 4.06142 \\
\hline & 2018 & 0.22578 & 0.02484 & 0.01541 & 0.11299 & 5.78762 \\
\hline \multirow[t]{4}{*}{ UMB } & 2015 & 0.07453 & $(0.00570)$ & $(0.00040)$ & 0.11413 & 0.80653 \\
\hline & 2016 & 0.29799 & $(0.04577)$ & 0.98163 & 0.06271 & 0.70372 \\
\hline & 2017 & 0.24183 & $(0.03654)$ & 0.22946 & 0.07656 & 0.96235 \\
\hline & 2018 & 0.18251 & $(0.02818)$ & 0.94606 & 0.10813 & 1.30783 \\
\hline \multirow[t]{4}{*}{ ZTB } & 2015 & 0.13457 & 0.10213 & 0.00726 & 0.20549 & 2.26253 \\
\hline & 2016 & $(0.24092)$ & 0.11152 & 0.59520 & 0.20318 & 1.05153 \\
\hline & 2017 & $(0.32117)$ & 0.09830 & 0.53586 & 0.19026 & 0.90954 \\
\hline & 2018 & $(0.49127)$ & 0.03701 & 0.68523 & 0.18556 & 1.02343 \\
\hline \multirow[t]{4}{*}{ SBG } & 2015 & 0.08479 & 0.05682 & 0.10558 & 0.08949 & 1.17187 \\
\hline & 2016 & 0.12237 & 0.04041 & 0.04122 & 0.14797 & 1.83862 \\
\hline & 2017 & 0.16923 & 0.09181 & 0.59310 & 0.21114 & 2.43291 \\
\hline & 2018 & 0.16853 & 0.03593 & 0.54126 & 0.20962 & 2.41170 \\
\hline
\end{tabular}

Source: Financial Reports (2015-2018). 
(C)

\begin{tabular}{|c|c|c|c|c|c|}
\hline & \multicolumn{5}{|c|}{ DATA PRESENTATION OF TAFFLER Z-SCORE VARIABLES } \\
\hline BANK CODE & YEARS & PBT/CL (X1) & $\mathrm{CA} / \mathrm{TL}(\mathrm{X} 2)$ & CL/TA (X3) & QA-CL/OPC-DEP (X4) \\
\hline \multirow[t]{4}{*}{ FAB } & 2015 & 0.13973 & 0.77383 & 0.79740 & $(1.38201)$ \\
\hline & 2016 & 0.13669 & 1.06000 & 0.83508 & 0.80085 \\
\hline & 2017 & 0.09762 & 1.05873 & 0.85393 & 0.09396 \\
\hline & 2018 & 0.11629 & 1.13519 & 0.80242 & 1.80337 \\
\hline \multirow[t]{4}{*}{ BAB } & 2015 & 0.08593 & 1.16243 & 0.83039 & 1.60337 \\
\hline & 2016 & 0.09512 & 1.04686 & 0.84123 & 2.71024 \\
\hline & 2017 & 0.11340 & 1.20085 & 0.81495 & 3.22645 \\
\hline & 2018 & 0.00730 & 1.16285 & 0.84463 & 3.43216 \\
\hline \multirow[t]{4}{*}{$\mathrm{BOA}$} & 2015 & 0.05315 & 11.21326 & 0.64856 & 1.65916 \\
\hline & 2016 & 0.02561 & 1.11564 & 0.85676 & 1.36098 \\
\hline & 2017 & 0.03556 & 1.11296 & 0.69927 & 3.05705 \\
\hline & 2018 & 0.04434 & 1.14263 & 0.66991 & 3.50362 \\
\hline \multirow[t]{4}{*}{ CAL } & 2015 & $(0.06518)$ & 1.13083 & 0.80244 & 3.10001 \\
\hline & 2016 & 0.00409 & 1.07845 & 0.82026 & 1.13932 \\
\hline & 2017 & 0.06094 & 1.09839 & 0.81161 & 2.16377 \\
\hline & 2018 & 0.05517 & 1.06662 & 0.77237 & 2.78355 \\
\hline \multirow[t]{4}{*}{ EGH } & 2015 & 0.01128 & 0.30076 & 0.22868 & 2.16330 \\
\hline & 2016 & $(0.00467)$ & 1.03128 & 0.84384 & 1.77970 \\
\hline & 2017 & 0.04989 & 1.06436 & 0.86910 & 1.25927 \\
\hline & 2018 & 0.04074 & 1.08710 & 0.86047 & 1.81962 \\
\hline \multirow[t]{4}{*}{$\mathrm{ABG}$} & 2015 & 0.66331 & 0.26193 & 0.17061 & 1.08148 \\
\hline & 2016 & 0.71881 & 0.21584 & 0.20741 & 0.87192 \\
\hline & 2017 & 0.24104 & 0.75721 & 0.03815 & 10.51561 \\
\hline & 2018 & 0.96896 & 0.82841 & 0.03758 & 10.35018 \\
\hline \multirow[t]{4}{*}{ GCB } & 2015 & 0.08432 & 1.28727 & 0.75456 & 9.49406 \\
\hline & 2016 & 0.16434 & 1.21923 & 0.80077 & 1.71940 \\
\hline & 2017 & 0.20878 & 1.26166 & 0.77292 & 2.33653 \\
\hline & 2018 & 2.07343 & 1.08387 & 0.84396 & 3.09116 \\
\hline \multirow[t]{4}{*}{ FBL } & 2015 & 0.06296 & 1.11089 & 0.79459 & 2.24791 \\
\hline & 2016 & 0.00557 & 1.10447 & 0.79869 & 1.69132 \\
\hline & 2017 & 0.03254 & 1.08115 & 0.77352 & 2.85124 \\
\hline & 2018 & 0.05271 & 1.08620 & 0.65464 & 5.34913 \\
\hline \multirow[t]{4}{*}{$\mathrm{ADB}$} & 2015 & 0.09687 & 1.16456 & 0.78106 & 2.08787 \\
\hline & 2016 & 0.09904 & 1.15544 & 0.74570 & 2.27264 \\
\hline & 2017 & 0.04126 & 1.10317 & 0.78320 & 2.45193 \\
\hline & 2018 & 0.04979 & 1.09593 & 0.84294 & 1.71295 \\
\hline \multirow[t]{4}{*}{ FNB } & 2015 & $(0.31610)$ & 0.53273 & 0.10029 & 4.66526 \\
\hline & 2016 & $(0.05563)$ & 1.76646 & 0.51577 & 3.14370 \\
\hline & 2017 & $(0.22963)$ & 1.92431 & 0.45865 & 2.13031 \\
\hline & 2018 & $(0.20764)$ & 2.94452 & 0.27733 & 5.58831 \\
\hline \multirow[t]{4}{*}{ GTB } & 2015 & 0.07371 & 1.15065 & 0.67326 & 8.97373 \\
\hline & 2016 & 0.08536 & 1.16282 & 0.69034 & 8.81756 \\
\hline & 2017 & 0.10171 & 1.19716 & 0.68800 & 11.60808 \\
\hline & 2018 & 0.10655 & 1.16090 & 0.74592 & 6.63016 \\
\hline \multirow[t]{4}{*}{ RBGH } & 2015 & $(0.02874)$ & 1.06152 & 0.82360 & 1.43503 \\
\hline & 2016 & $(0.03406)$ & 1.01681 & 0.90141 & 0.32431 \\
\hline & 2017 & 0.03082 & 1.08402 & 0.88413 & 1.23274 \\
\hline & 2018 & 0.02010 & 1.20495 & 0.78797 & 2.90682 \\
\hline \multirow[t]{4}{*}{ SOGEGH } & 2015 & 0.04315 & 1.10192 & 0.74904 & 2.10459 \\
\hline & 2016 & 0.04797 & 1.11428 & 0.78223 & 1.96420 \\
\hline & 2017 & 0.05863 & 1.10386 & 0.77667 & 1.38758 \\
\hline & 2018 & 0.04421 & 1.14925 & 0.69359 & 2.76404 \\
\hline SCB & 2015 & 0.03327 & 1.18720 & 0.81227 & 2.73862 \\
\hline
\end{tabular}




\begin{tabular}{|c|c|c|c|c|c|}
\hline & 2016 & 0.09805 & 1.20329 & 0.80583 & 4.35861 \\
\hline & 2017 & 0.11209 & 1.23058 & 0.78865 & 4.11432 \\
\hline & 2018 & 0.07016 & 1.20005 & 0.77913 & 4.49149 \\
\hline \multirow[t]{4}{*}{ TBL } & 2015 & 0.04140 & 0.96504 & 0.85608 & $(0.45559)$ \\
\hline & 2016 & 0.02574 & 0.96246 & 0.86336 & $(0.56178)$ \\
\hline & 2017 & 0.02216 & 0.97127 & 0.88533 & $(0.48600)$ \\
\hline & 2018 & 0.02094 & 0.98062 & 0.89541 & $(0.38636)$ \\
\hline \multirow[t]{4}{*}{ UBA } & 2015 & 0.04876 & 0.48286 & 0.76617 & $(5.83070)$ \\
\hline & 2016 & 3.81259 & 0.76148 & 0.01477 & 11.74051 \\
\hline & 2017 & 0.02602 & 1.07909 & 0.69198 & 5.90279 \\
\hline & 2018 & 0.02154 & 1.04763 & 0.71550 & 6.59923 \\
\hline \multirow[t]{4}{*}{ UMB } & 2015 & $(0.00044)$ & 14.56136 & 0.89632 & 2.05092 \\
\hline & 2016 & 1.45691 & 1.03270 & 0.67378 & 5.43577 \\
\hline & 2017 & 0.31377 & 1.04762 & 0.73129 & 3.59765 \\
\hline & 2018 & 1.23462 & 1.05137 & 0.76627 & 1.73881 \\
\hline \multirow[t]{4}{*}{ ZTB } & 2015 & 0.00876 & 1.16103 & 0.82856 & 1.34576 \\
\hline & 2016 & 0.74514 & 0.67119 & 0.79877 & $(5.59794)$ \\
\hline & 2017 & 0.70170 & 0.52667 & 0.76366 & $(9.27219)$ \\
\hline & 2018 & 0.82974 & 0.39666 & 0.82584 & $(10.11426)$ \\
\hline \multirow[t]{4}{*}{ SBG } & 2015 & 0.11887 & 1.12819 & 0.88822 & 1.46071 \\
\hline & 2016 & 0.04862 & 1.11387 & 0.84793 & 2.36077 \\
\hline & 2017 & 0.74100 & 1.17437 & 0.80041 & 3.13786 \\
\hline & 2018 & 0.67231 & 1.17769 & 0.80508 & 2.70348 \\
\hline
\end{tabular}

Source: Financial Reports (2015 - 2018).

(D)

\begin{tabular}{|c|c|c|c|c|c|c|c|c|c|}
\hline & \multicolumn{9}{|c|}{ DATA PRESENTATION OF BENEISH M-SCORE VARIABLES } \\
\hline Bank Code & YEARS & TATAI & (LEVI) & DSRI & GMI & AQI & SGI & DEPI & SGAI \\
\hline \multirow[t]{4}{*}{ FAB } & 2015 & $(0.12736)$ & 0.87355 & 2.04103 & 0.97086 & 0.99865 & 0.73377 & 1.35232 & 2.40772 \\
\hline & 2016 & 0.06601 & 0.85626 & 0.06636 & 1.04322 & 0.94563 & 5.08695 & 0.48734 & 0.25299 \\
\hline & 2017 & 0.05419 & 0.86478 & 0.63342 & 1.00198 & 1.00836 & 1.69140 & 1.22402 & 0.64019 \\
\hline & 2018 & 0.11449 & 0.81438 & 3.58674 & 0.99103 & 1.00976 & 0.43220 & 1.13007 & 2.79471 \\
\hline \multirow[t]{4}{*}{ BAB } & 2015 & 0.14108 & 0.83843 & 1.17920 & 0.99932 & 1.00119 & 0.96275 & 0.84558 & 1.26688 \\
\hline & 2016 & 0.13933 & 0.93929 & 1.35448 & 0.99929 & 1.00356 & 0.90162 & 1.11556 & 0.39700 \\
\hline & 2017 & 0.17083 & 0.82323 & 1.13664 & 0.99877 & 1.00158 & 1.08962 & 1.13938 & 0.91539 \\
\hline & 2018 & 0.14339 & 0.85130 & 1.20869 & 0.99811 & 1.00405 & 1.02256 & 1.12359 & 1.27524 \\
\hline \multirow[t]{4}{*}{ BOA } & 2015 & 0.33489 & 0.08792 & 0.17929 & 2.41022 & 1.00003 & 6.38383 & 0.95646 & 0.16023 \\
\hline & 2016 & 0.09564 & 0.85676 & 0.68902 & 1.06481 & 0.96628 & 1.67454 & 0.32520 & 1.89957 \\
\hline & 2017 & 0.25319 & 0.85967 & 0.93501 & 0.98571 & 0.99990 & 1.18592 & 1.22924 & 0.87592 \\
\hline & 2018 & 0.27881 & 0.83458 & 1.55738 & 0.97757 & 0.99848 & 0.73187 & 1.08702 & 1.68541 \\
\hline \multirow[t]{4}{*}{ CAL } & 2015 & 0.15624 & 0.84904 & 1.11722 & 0.99880 & 0.98913 & 1.20844 & 0.50356 & 1.19189 \\
\hline & 2016 & 0.10600 & 0.86032 & 1.42081 & 0.98135 & 0.96752 & 0.76628 & 0.60635 & 1.62051 \\
\hline & 2017 & 0.11600 & 0.84631 & 0.57291 & 1.01508 & 1.00421 & 1.64541 & 1.33485 & 0.67127 \\
\hline & 2018 & 0.14123 & 0.85857 & 1.00738 & 1.00399 & 0.98459 & 1.30024 & 0.90282 & 0.92358 \\
\hline \multirow[t]{4}{*}{ EGH } & 2015 & 0.03922 & 0.89287 & 0.88754 & 1.00020 & 0.99476 & 1.29722 & 0.63709 & 0.91423 \\
\hline & 2016 & 0.09391 & 0.91399 & 3.71994 & 0.99584 & 0.96665 & 0.92056 & 1.76610 & 2.84838 \\
\hline & 2017 & 0.08115 & 0.89484 & 0.57078 & 1.00380 & 0.99660 & 0.58762 & 0.44623 & 0.23342 \\
\hline & 2018 & 0.09170 & 0.87831 & 1.05836 & 1.00011 & 1.00276 & 1.13616 & 1.26243 & 0.99402 \\
\hline \multirow[t]{4}{*}{$\mathrm{ABG}$} & 2015 & 0.55174 & 2.85738 & 9.33722 & 0.27948 & 0.96126 & 0.26334 & 4.26838 & 4.68279 \\
\hline & 2016 & 0.53623 & 3.57919 & 1.06138 & 1.54276 & 0.95274 & 1.40173 & 0.96417 & 1.02516 \\
\hline & 2017 & 0.48761 & 0.70165 & 0.63036 & 1.05511 & 1.32267 & 1.37466 & 1.36625 & 0.78617 \\
\hline & 2018 & 0.43175 & 0.57272 & 0.92052 & 1.38248 & 1.00887 & 1.35853 & 1.17294 & 0.86283 \\
\hline \multirow[t]{4}{*}{ GCB } & 2015 & 0.21108 & 0.75456 & 0.71497 & 0.99956 & 1.00032 & 1.08425 & 1.71572 & 0.79464 \\
\hline & 2016 & 0.17010 & 0.80081 & 0.74905 & 0.99361 & 1.00282 & 1.02993 & 1.07818 & 2.70501 \\
\hline & 2017 & 0.19343 & 0.77291 & 0.73288 & 0.98826 & 0.99798 & 0.97713 & 1.32928 & 1.20286 \\
\hline & 2018 & 0.13345 & 0.90470 & 5.37542 & 1.01247 & 1.00601 & 0.00710 & 0.57035 & 0.81512 \\
\hline
\end{tabular}




\begin{tabular}{|c|c|c|c|c|c|c|c|c|c|}
\hline \multirow[t]{4}{*}{ FBL } & 2015 & 0.17628 & 0.87750 & 7.28427 & 0.99736 & 1.00521 & 1.23136 & 1.07526 & 1.26043 \\
\hline & 2016 & 0.17277 & 0.88179 & 0.93725 & 0.99744 & 0.99897 & 0.94159 & 0.63394 & 1.00773 \\
\hline & 2017 & 0.19838 & 0.90067 & 0.74928 & 1.00218 & 1.00161 & 1.04227 & 0.82576 & 1.12308 \\
\hline & 2018 & 0.32124 & 0.90142 & 1.24547 & 0.99853 & 1.00511 & 1.10997 & 2.09129 & 1.07798 \\
\hline \multirow[t]{4}{*}{ ADB } & 2015 & 0.17146 & 0.82361 & 1.36596 & 0.99711 & 0.99904 & 0.92733 & 1.23488 & 1.04612 \\
\hline & 2016 & 0.20902 & 0.83220 & 0.58409 & 1.00490 & 0.99859 & 1.85207 & 0.98845 & 0.75059 \\
\hline & 2017 & 0.18546 & 0.88354 & 1.11474 & 0.99209 & 1.00854 & 1.12880 & 1.15741 & 1.12825 \\
\hline & 2018 & 0.10780 & 0.87537 & 0.79365 & 1.00342 & 1.00103 & 1.63283 & 1.35224 & 0.59986 \\
\hline \multirow[t]{4}{*}{ FNB } & 2015 & 0.79539 & 1.69639 & - & 0.99995 & 0.93398 & 5.49474 & - & 144.34836 \\
\hline & 2016 & 0.39450 & 0.52147 & 1.67416 & 0.97885 & 0.99422 & 1.43924 & 1.22260 & 1.00144 \\
\hline & 2017 & 0.43303 & 0.47373 & 4.33460 & 1.00716 & 0.98735 & 2.00035 & 1.47458 & 0.75301 \\
\hline & 2018 & 0.68099 & 0.32879 & 2.38361 & 0.99586 & 1.06000 & 1.24505 & 1.26008 & 1.08768 \\
\hline \multirow[t]{4}{*}{ GTB } & 2015 & 0.26774 & 0.82192 & 1.04040 & 0.99867 & 0.99713 & 1.02898 & 0.89016 & 3.02242 \\
\hline & 2016 & 0.25540 & 0.81751 & 1.34736 & 0.99368 & 1.00363 & 0.83096 & 1.12438 & 1.34232 \\
\hline & 2017 & 0.25935 & 0.79519 & 0.99597 & 1.00364 & 1.00122 & 0.89691 & 0.98708 & 0.92849 \\
\hline & 2018 & 0.19067 & 0.81130 & 0.29187 & 1.00651 & 0.99441 & 2.89042 & 0.96908 & 0.43170 \\
\hline \multirow[t]{4}{*}{ RBGH } & 2015 & 0.11040 & 0.88524 & 1.31378 & 0.97447 & 1.00246 & 1.05623 & 1.52684 & 1.76632 \\
\hline & 2016 & 0.03163 & 0.92396 & 0.25096 & 1.04318 & 1.00316 & 3.96415 & 1.19334 & 1.17678 \\
\hline & 2017 & 0.07578 & 0.89121 & 0.65632 & 1.00563 & 1.00290 & 1.34140 & 1.03870 & 0.47293 \\
\hline & 2018 & 0.20299 & 0.82585 & 1.12464 & 1.00511 & 1.00998 & 1.29004 & 0.97993 & 1.14212 \\
\hline \multirow[t]{4}{*}{ SOGEGH } & 2015 & 0.20162 & 0.86750 & 1.11415 & 0.99816 & 2.02244 & 0.91576 & 12.32081 & 0.57734 \\
\hline & 2016 & 0.17614 & 0.86420 & 0.86188 & 0.99702 & 1.00785 & 1.21351 & 1.05214 & 0.98975 \\
\hline & 2017 & 0.11704 & 0.81401 & 0.71660 & 1.01218 & 0.93335 & 2.08743 & 0.40588 & 0.63491 \\
\hline & 2018 & 0.21398 & 0.79548 & 0.80851 & 1.00182 & 1.01739 & 1.46123 & 1.57642 & 0.64209 \\
\hline \multirow[t]{4}{*}{ SCB } & 2015 & 0.17738 & 0.83525 & 0.79138 & 0.99913 & 0.99984 & 1.20539 & 1.03168 & 0.37910 \\
\hline & 2016 & 0.18543 & 0.82504 & 1.08387 & 1.00092 & 1.00064 & 0.95529 & 0.86455 & 0.50886 \\
\hline & 2017 & 0.20321 & 0.80725 & 1.37069 & 0.99729 & 1.00011 & 0.80066 & 1.02803 & 2.25762 \\
\hline & 2018 & 0.20872 & 0.82424 & 0.86677 & 1.00072 & 0.99571 & 1.20450 & 0.55899 & 0.95604 \\
\hline \multirow[t]{4}{*}{ TBL } & 2015 & $(0.04332)$ & 0.85680 & 1.00942 & 0.99721 & 0.94267 & 0.98689 & 0.89593 & 0.98721 \\
\hline & 2016 & $(0.04723)$ & 0.86380 & 0.35272 & 1.02300 & 1.00893 & 2.31636 & 1.12979 & 0.49273 \\
\hline & 2017 & $(0.03926)$ & 0.88562 & 0.96918 & 1.00308 & 1.02171 & 1.18152 & 1.07126 & 0.89139 \\
\hline & 2018 & $(0.03104)$ & 0.89564 & 0.99269 & 1.00853 & 1.01383 & 1.64472 & 1.09156 & 0.51339 \\
\hline \multirow[t]{4}{*}{ UBA } & 2015 & $(0.33721)$ & 0.89025 & 9.47268 & $(9.00605)$ & 1.03150 & 1.18290 & 3.71135 & 8.73201 \\
\hline & 2016 & 0.67890 & 0.91197 & 1.97963 & 3.43736 & 1.00050 & 0.89124 & 0.97162 & 1.76830 \\
\hline & 2017 & 0.23717 & 0.86327 & 0.04508 & $(0.03237)$ & 0.97319 & 1.43412 & 0.42678 & 0.00062 \\
\hline & 2018 & 0.22336 & 0.89848 & 0.59023 & 1.00177 & 1.00341 & 1.74557 & 1.11467 & 0.60786 \\
\hline \multirow[t]{4}{*}{ UMB } & 2015 & 0.07402 & 0.06667 & 3.25811 & 0.99914 & 1.01231 & 0.38833 & 3.65321 & 2.10277 \\
\hline & 2016 & 0.29321 & 0.94099 & 0.87329 & 0.91847 & 0.98045 & 0.12749 & 1.07849 & 2.58428 \\
\hline & 2017 & 0.23576 & 0.92888 & 0.23028 & 0.99607 & 1.00039 & 1.46337 & 1.22781 & 0.79281 \\
\hline & 2018 & 0.17408 & 0.90242 & 0.65000 & 1.02942 & 0.97830 & 1.14870 & 0.75147 & 1.08320 \\
\hline \multirow[t]{4}{*}{ ZTB } & 2015 & 0.13191 & 0.82954 & 0.67250 & 0.97468 & 0.96989 & 1.33214 & 0.22622 & 2.53507 \\
\hline & 2016 & $(0.24352)$ & 0.83113 & 1.37128 & 1.52304 & 0.99589 & 0.75074 & 0.88351 & 0.59038 \\
\hline & 2017 & $(0.32390)$ & 0.84015 & 0.66921 & 1.15270 & 0.99854 & 1.18811 & 1.01343 & 1.08840 \\
\hline & 2018 & $(0.49446)$ & 0.84348 & 0.67930 & 0.84945 & 1.00718 & 1.34113 & 1.37946 & 1.09376 \\
\hline \multirow[t]{4}{*}{ SBG } & 2015 & 0.08108 & 0.86244 & 0.21917 & 1.01192 & 0.99845 & 4.25887 & 0.94960 & 0.27222 \\
\hline & 2016 & 0.11819 & 0.87110 & 2.70408 & 0.99341 & 1.01398 & 1.63100 & 1.96709 & 1.91773 \\
\hline & 2017 & 0.16338 & 0.82567 & 0.86830 & 1.00407 & 0.99847 & 1.28730 & 1.09252 & 0.57179 \\
\hline & 2018 & 0.16286 & 0.82671 & 1.17972 & 1.00169 & 1.00077 & 1.16867 & 1.10107 & 1.60285 \\
\hline
\end{tabular}

Source: Financial Reports (2015 - 2018). 